Prepared in cooperation with the Oklahoma Department of Transportation

\title{
Methods for Estimating the Magnitude and Frequency of Peak Streamflows for Unregulated Streams in Oklahoma
}

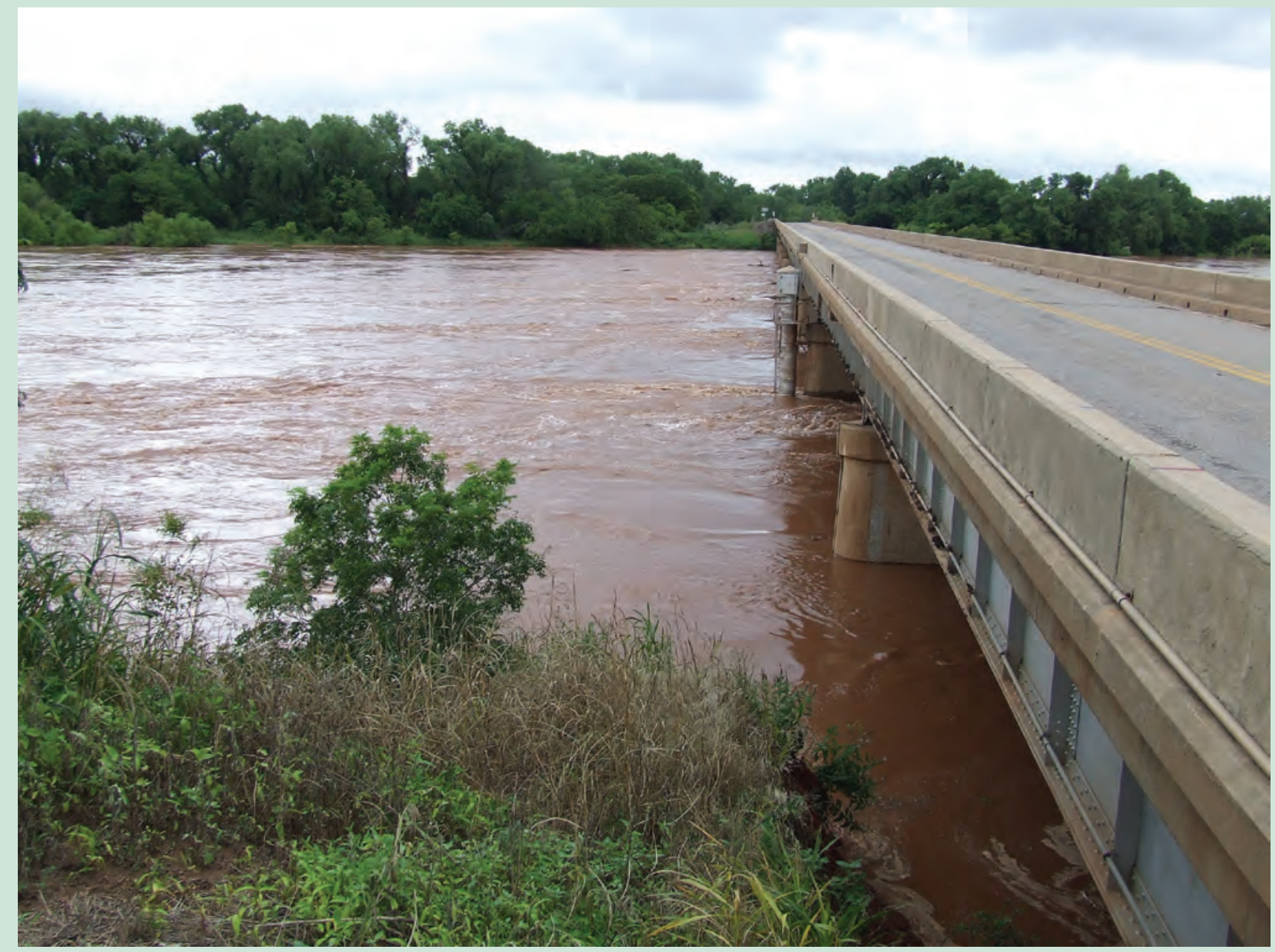

Scientific Investigations Report 2010-5137 
On Cover: Photograph of the Cimarron River near Guthrie (U.S. Geological Survey station number 07160000) taken by Martin Schneider, U.S. Geological staff. 


\section{Methods for Estimating the Magnitude and Frequency of Peak Streamflows for Unregulated Streams in Oklahoma}

By Jason M. Lewis

Prepared in cooperation with the Oklahoma Department of Transportation

Scientific Investigations Report 2010-5137 


\section{U.S. Department of the Interior \\ KEN SALAZAR, Secretary \\ U.S. Geological Survey \\ Marcia K. McNutt, Director}

U.S. Geological Survey, Reston, Virginia: 2010

This and other USGS information products are available at http://store.usgs.gov/
U.S. Geological Survey
Box 25286 , Denver Federal Center
Denver, CO 80225
To learn about the USGS and its information products visit http://www.usgs.gov/
1-888-ASK-USGS

Any use of trade, product, or firm names is for descriptive purposes only and does not imply endorsement by the U.S. Government.

Although this report is in the public domain, permission must be secured from the individual copyright owners to reproduce any copyrighted materials contained within this report.

Suggested citation:

Lewis, J.M., 2010, Methods for Estimating the Magnitude and Frequency of Peak Streamflows for Unregulated Streams in Oklahoma: U.S. Geological Survey Scientific Investigations Report SIR 2010-5137, 41 p. 


\section{Contents}

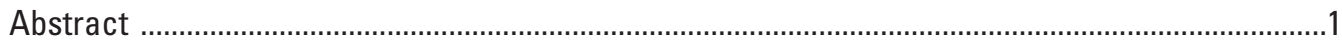

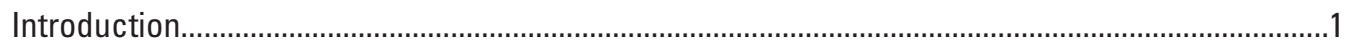

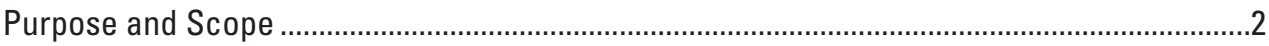

General Description and Effects of Floodwater Retarding Structures ......................................

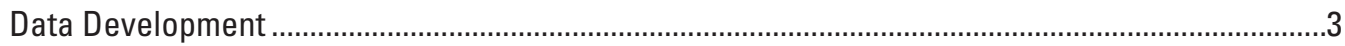

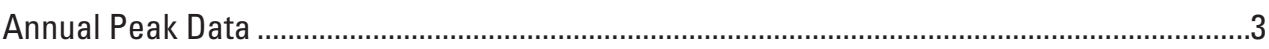

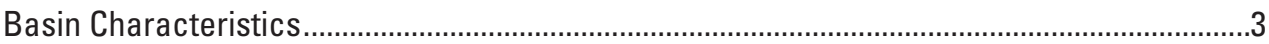

Estimate of Magnitude and Frequency of Peak Streamflows at Streamflow-Gaging Stations on Unregulated Streams ....................................................................................................

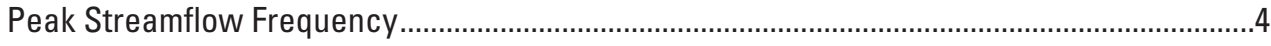

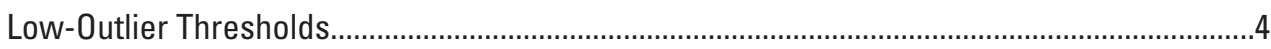

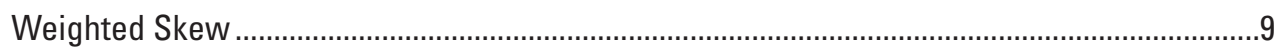

Generalized-Skew Analysis .................................................................................................

Estimate of Magnitude and Frequency of Peak Streamflows at Ungaged Sites on Unregulated Streams .......................................................................................................

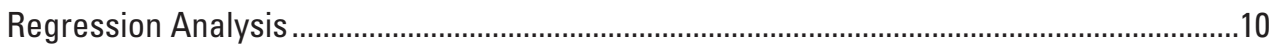

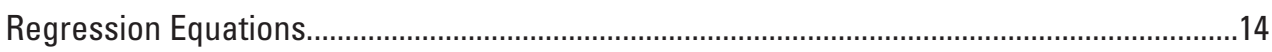

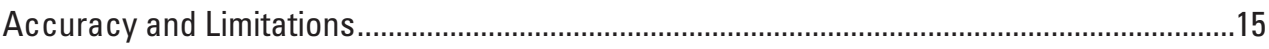

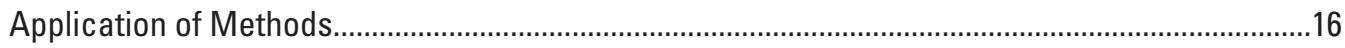

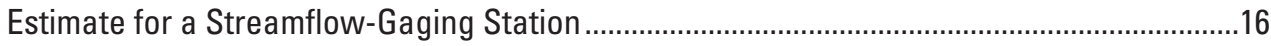

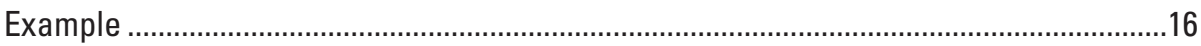

Estimate for an Ungaged Site near a Streamflow-Gaging Station ...........................................18

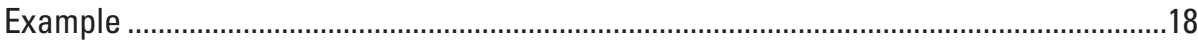

Adjustment for Ungaged Sites on Urban Streams ………...................................................19

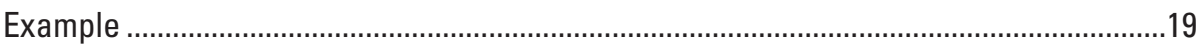

Adjustment for Ungaged Sites on Streams Regulated by Floodwater

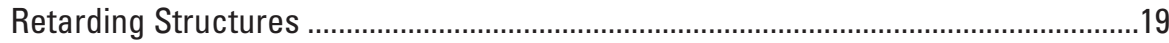

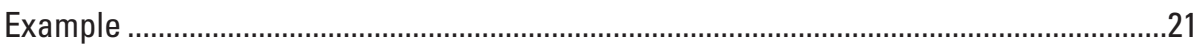

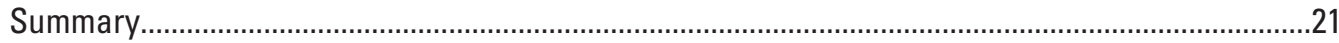

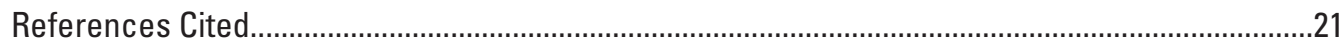

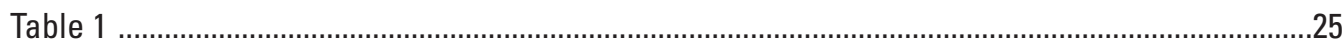

\section{Figures}

1-3. Maps showing:

1. Location of streamflow-gaging stations with unregulated periods of record used in report.

2. Generalized skew coefficients of logarithms of annual maximum streamflow for Oklahoma streams with drainage area less than or equal to 2,510 square miles.

3. Residuals from the 10-percent chance exceedance ordinary least squares (OLS) regression model for each site. 
4. Scatterplots showing performance metrics from computer program WREG (A) residuals, (B) leverage, and (C) influence for a 10-percent chance exceedance peak-streamflow regression model.

5. WREG output for the 10-percent chance exceedance peak-streamflow regression model by using the generalized least squares (GLS) method, showing average standard error of prediction (Sp \%), the pseudo coefficient of determination (Pseudo $\mathrm{R}_{2}$ ), and standard model error, in percent (\%).

6. Graph showing relation of urban adjustment factor, $\mathrm{R}_{\mathrm{L}}$, to the percentage of area impervious, and served by storm sewer.

\section{Tables}

2. Basin characteristics investigated as possible independent variables for regressions used to estimate peak streamflows for unregulated streams

3. T-year recurrence intervals with corresponding annual exceedance probabilities and P-percent chance exceedances for peak-streamflow frequency estimates.............9

4. Accuracy of peak streamflows estimated for unregulated streams in Oklahoma..........16

5. Weighted peak-streamflow frequency estimates for Kiamichi River near Big Cedar, Oklahoma (07335700)

\section{Conversion Factors and Datums}

\begin{tabular}{|c|c|c|}
\hline Multiply & By & To obtain \\
\hline \multicolumn{3}{|c|}{ Length } \\
\hline inch (in.) & 2.54 & centimeter $(\mathrm{cm})$ \\
\hline inch (in.) & 25.4 & millimeter (mm) \\
\hline foot (ft) & 0.3048 & $\operatorname{meter}(\mathrm{m})$ \\
\hline mile (mi) & 1.609 & kilometer $(\mathrm{km})$ \\
\hline yard (yd) & 0.9144 & meter $(\mathrm{m})$ \\
\hline \multicolumn{3}{|c|}{ Area } \\
\hline acre & 4,047 & square meter $\left(\mathrm{m}^{2}\right)$ \\
\hline acre & 0.4047 & hectare (ha) \\
\hline square mile $\left(\mathrm{mi}^{2}\right)$ & 2.590 & square kilometer $\left(\mathrm{km}^{2}\right)$ \\
\hline \multicolumn{3}{|c|}{ Volume } \\
\hline cubic mile $\left(\mathrm{mi}^{3}\right)$ & 4.168 & cubic kilometer $\left(\mathrm{km}^{3}\right)$ \\
\hline acre-foot (acre-ft) & 1,233 & cubic meter $\left(\mathrm{m}^{3}\right)$ \\
\hline acre-foot (acre-ft) & 0.001233 & cubic hectometer $\left(\mathrm{hm}^{3}\right)$ \\
\hline \multicolumn{3}{|c|}{ Flow rate } \\
\hline cubic foot per second $\left(\mathrm{ft}^{3} / \mathrm{s}\right)$ & 0.02832 & cubic meter per second $\left(\mathrm{m}^{3} / \mathrm{s}\right)$ \\
\hline $\begin{array}{l}\text { cubic foot per second per square } \\
\text { mile }\left[\left(\mathrm{ft}^{3} / \mathrm{s}\right) / \mathrm{mi}^{2}\right]\end{array}$ & 0.01093 & $\begin{array}{l}\text { cubic meter per second per square } \\
\text { kilometer }\left[\left(\mathrm{m}^{3} / \mathrm{s}\right) / \mathrm{km}^{2}\right]\end{array}$ \\
\hline \multicolumn{3}{|c|}{ Hydraulic gradient } \\
\hline foot per mile ( $\mathrm{ft} / \mathrm{mi})$ & 0.1894 & meter per kilometer $(\mathrm{m} / \mathrm{km})$ \\
\hline
\end{tabular}

Water year is the 12-month period October 1 through September 30, designated by the calendar year in which 
the water year ends.

Vertical coordinate information is referenced to the North American Vertical Datum of 1988 (NAVD 88).

Horizontal coordinate information is referenced to the North American Datum of 1983 (NAD 83).

Altitude, as used in this report, refers to distance above the vertical datum. 


\title{
Methods for Estimating the Magnitude and Frequency of Peak Streamflows for Unregulated Streams in Oklahoma
}

\author{
By Jason M. Lewis
}

\begin{abstract}
Peak-streamflow regression equations were determined for estimating flows with exceedance probabilities from 50 to 0.2 percent for the state of Oklahoma. These regression equations incorporate basin characteristics to estimate peakstreamflow magnitude and frequency throughout the state by use of a generalized least squares regression analysis. The most statistically significant independent variables required to estimate peak-streamflow magnitude and frequency for unregulated streams in Oklahoma are contributing drainage area, mean-annual precipitation, and main-channel slope. The regression equations are applicable for watershed basins with drainage areas less than 2,510 square miles that are not affected by regulation. The resulting regression equations had a standard model error ranging from 31 to 46 percent.

Annual-maximum peak flows observed at 231 streamflow-gaging stations through water year 2008 were used for the regression analysis. Gage peak-streamflow estimates were used from previous work unless 2008 gaging-station data were available, in which new peak-streamflow estimates were calculated. The U.S. Geological Survey StreamStats web application was used to obtain the independent variables required for the peak-streamflow regression equations. Limitations on the use of the regression equations and the reliability of regression estimates for natural unregulated streams are described. Log-Person Type III analysis information, basin and climate characteristics, and the peak-streamflow frequency estimates for the 231 gaging stations in and near Oklahoma are listed.

Methodologies are presented to estimate peak streamflows at ungaged sites by using estimates from gaging stations on unregulated streams. For ungaged sites on urban streams and streams regulated by small floodwater retarding structures, an adjustment of the statewide regression equations for natural unregulated streams can be used to estimate peak-streamflow magnitude and frequency.
\end{abstract}

\section{Introduction}

Estimates of the magnitude and frequency of floods is required for the safe and economical design of highway bridges, culverts, dams, levees, and other structures on or near streams. Flood plain management programs and flood-insurance rates also are based on flood magnitude and frequency information. Estimates of the magnitude and frequency of flooding events, or peak streamflows, are commonly needed at ungaged sites with no streamflow data available. Regional regression equations can be used to estimate peak streamflows at ungaged sites.

The U.S. Department of Agriculture, Natural Resources Conservation Service (NRCS) has constructed several floodwater retarding structures throughout Oklahoma that regulate flood peaks. Currently (2010), about 2,105 floodwater retarding structures are in more than 120 watershed basins in Oklahoma. On completion of the NRCS watershed protection and flood prevention program (G.W. Utley, Natural Resources Conservation Service, written commun., 1997) about 2,500 floodwater retarding structures will regulate flood peaks for about 8,500 square miles ( $\mathrm{mi}^{2}$ ) (about 12 percent) of the state. By design, floodwater retarding structures decrease the magnitude of main-stem flood peaks and decrease the rate of runoff recession of single storms (Bergman and Huntzinger, 1981). Consideration of the flood peak modification capability of floodwater retarding structures can result in more hydraulically efficient, cost-effective culvert or bridge designs along downstream segments of streams regulated by floodwater retarding structures (Tortorelli, 1997).

The U.S. Geological Survey (USGS), in cooperation with the Oklahoma Department of Transportation, updated the regression equations for estimating peak-streamflow frequencies for Oklahoma streams with a drainage area less than 2,510 $\mathrm{mi}^{2}$, as suggested by Tortorelli (1997). The methods used in this report should provide more accurate estimates of peak flows for Oklahoma than previous reports (Tortorelli, 
1997; Tortorelli and Bergman, 1985) because of the use of additional data and more rigorous statistical procedures. The generalized least squares (GLS) regression method was used in this report, as opposed to the weighted least squares method used in Tortorelli (1997) to better handle cross-correlation of peak streamflow between gaging stations and differing historic record lengths.

\section{Purpose and Scope}

This report presents methods for estimating the magnitude and frequency of peak streamflows for the 50-, 20-, 10-, 4-, 2-, 1-, and 0.2-percent chance exceedance floods for ungaged sites on unregulated streams with drainage areas of less than 2,510 $\mathrm{mi}^{2}$ in Oklahoma. This report provides methods that can be used to estimate peak-streamflow frequencies for gaging stations on unregulated streams and by using this result to, in turn, estimate nearby ungaged sites on the same stream. Methods used to adjust estimates for ungaged urban streams and streams regulated by floodwater retarding structures also are presented. This report also provides peak streamflow frequency analyses and basin characteristics for all streamflow-gaging stations used in the regression analysis.

Flood-discharge records through the 2008 water year at 231 streamflow-gaging stations throughout Oklahoma and in bordering parts of Arkansas, Kansas, Missouri, and Texas were used to develop statewide peak-streamflow frequency estimate equations. Estimates of peak-streamflow frequency from the 231 gaging stations were related to climatic and physiographic attributes, referred to as basin characteristics, by using multiple-linear regression. The regression equations derived from these analyses provide methods to estimate flood frequencies of unregulated streams.

This report provides methods to estimate peak streamflows for streams with drainage areas less than 2,510 $\mathrm{mi}^{2}$. Peak-streamflow frequency for streams with greater than or equal to $2,510 \mathrm{mi}^{2}$ drainage areas can be estimated by using methods described in Sauer (1974a) and Lewis and Esralew (2009). The Oklahoma generalized skew map (Lewis and Esralew, 2009), a necessary element in the development of the peak-streamflow frequencies for the 231 gaging stations, was updated in 2008. In this report, methods are presented to estimate peak-streamflow frequencies at sites on urban streams (based on Sauer, 1974b) and streams regulated by floodwater retarding structures (based on Tortorelli and Bergman, 1985).

This report supercedes the report by Tortorelli (1997) to estimate peak-streamflow frequencies for unregulated Oklahoma streams with a drainage area less than 2,510 $\mathrm{mi}^{2}$. The current report incorporates (1) an additional 13 years of annual peak-streamflow data, with major peak-streamflows recorded during water years 1999, 2000, 2004, 2007, and 2008; (2) additional streamflow-gaging stations that now have adequate numbers of years for frequency analysis; (3) removal of gaging stations included in Tortorelli (1997) that were later determined to be influenced by regulation or were outside of the modified study area; (4) basin characteristics determined at each gaging station location by using a geographic information system (GIS); (5) mean-annual precipitation based on an updated period 1971-2000 and an area-weighted average of precipitation for the contributing drainage area, from which a point estimate of mean-annual precipitation was determined; and (6) a GLS regression method shown to be a better method at handling cross-correlation and differing record lengths of peak-streamflow at gaging stations (Tasker and Stedinger, 1989).

\section{General Description and Effects of Floodwater Retarding Structures}

This report includes an adjustment for the effects of floodwater retarding structures on peak streamflow because many areas of Oklahoma are regulated by these structures. Floodwater retarding structures built by the NRCS are used in watershed basin protection and flood-prevention programs.

Floodwater retarding structures generally consist of an earthen dam, a valved drain pipe, a drop inlet principal spillway, and an open-channel earthen emergency spillway (Moore, 1969). The principal spillway is ungated and automatically limits the rate at which water can flow from a reservoir. Most of the structures built in Oklahoma have release rates of 10 to 15 cubic feet per seconf per square mile $\left(\left(\mathrm{ft}^{3} / \mathrm{s}\right) / \mathrm{mi}^{2}\right)$. The space in a reservoir between the elevation of the principal spillway crest and the emergency spillway crest is used for floodwater detention.

Most floodwater retarding structures in Oklahoma are designed to draw down the floodwater-retarding pool in 10 days or less (R. C. Riley, Natural Resources Conservation Service, written commun., 1984). The 10-day drawdown requirement serves two purposes. First, most vegetation in the floodwater retarding pool will survive as much as 10 days of inundation without destroying the viability of the stand. Second, a 10-day drawdown period will substantially reduce the effect from repetitive storms (Tortorelli, 1997).

Floodwater retarding structures have embankment heights ranging generally from 20 to 60 feet (ft) and drainage areas ranging generally from 1 to $20 \mathrm{mi}^{2}$ (Moore, 1969). Storage capacity is limited to 12,500 acre-ft for floodwater detention and 25,000 acre-ft total for combined uses, including recreation, municipal and industrial water, and others (Tortorelli, 1997).

The emergency spillway design, including storage above the emergency crest, and capacity of an emergency spillway is influenced by the size of the floodwater retarding structure and the location of the structure in the basin. Design details may be found in the NRCS National Engineering Handbook, Section 4 (U.S. Soil Conservation Service, 1972).

The primary effect of a system of upstream floodwater retarding structures on a basin streamflow hydrograph at a point downstream from the floodwater retarding structures is that flood peak discharge is reduced. This reduction is related 
to the percentage of the overall basin that is regulated by the floodwater retarding structures (Hartman and others, 1967; Moore, 1969; Moore and Coskun, 1970; DeCoursey, 1975; Schoof and others, 1980). The slope of the recession segment of the hydrograph will decrease as the number of floodwater retarding structures where the principal spillways are flowing increases.

Several factors substantially influence the effectiveness of the floodwater retarding structures in reducing peak flow on the main stem downstream from the floodwater retarding structures (Hartman and others, 1967; Moore, 1969; Moore and Coskun, 1970; Schoof and others, 1980). Those factors include rainfall distribution over the basin, contents of the reservoirs before the storm, and distribution of floodwater retarding structures in the basin. For example, rainfall that is only on the basin area controlled by floodwater retarding structures will generally result in greater peak reduction. The structures are more effective in reducing the flood peak if the structures are empty before the storm. Structures in the upper end of an elongated basin are less effective than structures in a fan-shaped basin (Tortorelli, 1997).

\section{Data Development}

\section{Annual Peak Data}

The first step in peak-streamflow frequency analysis is the compilation and review of all streamflow-gaging stations with peak-streamflow data. Streamflow-gaging stations selected for analysis (fig. 1) were in 8-digit hydrologic unit boundaries (based on the 8-digit hydrologic unit codes, or HUCs) that were in or were adjacent to the Oklahoma state boundary (http://www.ncgc.nrcs.usda.gov/products/datasets watershed, accessed June 2009). Review was done to eliminate discrepancies in peak-streamflow data for gages across state lines. Peak-streamflow data from streamflow-gaging stations in the immediate bordering areas of Oklahoma with similar hydrologic characteristics also were selected for regression analysis.

The streamflow-gaging station flood-frequency analysis for natural unregulated streams of less than $2,510 \mathrm{mi}^{2}$ drainage area provided in this report is based on annual peak-streamflow data systematically collected at 231 gaging stations (table 1 , back of report).

The data were collected on the basis of a water year, from October 1 to September 30. Available data collected through September 30, 2008, were used from streamflow-gaging stations for this report. Only data from those streamflow-gaging stations with at least 8 years of flood peak data were used in the analysis. The Interagency Advisory Committee on Water Data (IACWD) recommends at least 10 years of data (Interagency Advisory Committee on Water Data, 1982). Asquith and Slade (1997) and Tortorelli (1997) used 8 years to utilize more streamflow-gaging stations to improve coverage in certain areas. Data from 8 streamflow-gaging stations with less than 10 years of peak-streamflow record were retained and carefully reviewed. All streamflow-gaging stations selected are on streams that are not substantially regulated by dams and floodwater retarding structures. Substantial regulation is defined as a contributing drainage basin where 20 percent or more of the basin is upstream of dams and floodwater retarding structures (Heimann and Tortorelli, 1988).

\section{Basin Characteristics}

Several basin characteristics were investigated for use as potential independent variables in the regression analyses. In this report, the basin characteristics (table 2) are the independent variables and the resulting peak-streamflow frequency values are the dependant variables.

Basin characteristics were calculated for each streamflow-gaging station by using geographic information system (GIS) techniques and the USGS StreamStats application (Ries and others, 2004; Ries and others, 2008, Smith and Esralew, $2010)$ to ensure consistency and reproducibility. Regression equations and flow statistics at gaging stations are integrated into the USGS StreamStats Web-based tool available at http:/ water.usgs.gov/osw/streamstats/index.htm. StreamStats allows users to obtain flow statistics, basin characteristics, and other information for user-selected stream locations. The user can 'point and click' on a stream location or a GIS-based interactive map of Oklahoma and StreamStats will delineate the drainage-basin upstream from the selected location, compute basin characteristics, and compute flow statistics at the ungaged stream locations by using regression estimates (Smith and Esralew, 2010).

Selection of the final characteristics were based on several factors including ease of measurement of the characteristic, coefficient of determination $\left(\mathrm{R}^{2}\right)$, Mallow's $\mathrm{Cp}$ statistic, multicollinearity, and statistical significance ( $\mathrm{p}$-value $<0.05$ ) of the independent variables. Multicollinearity among the independent variables was assessed by the variance inflation factor (VIF) that describes correlation among independent variables. Of the possible basin characteristics used in the regression analysis, contributing drainage-basin area (CONTDA), mean annual precipitation (PRECIP), and main channel 10-85 slope (CSL10_85fm) were selected as the most appropriate independent variables for the regression analyses. CONTDA, PRECIP, and CSL10_85fm short names were selected to be consistent with StreamStats terminology.

The contributing drainage-basin area can be defined by a point on a stream to which all areas in the basin contribute runoff. The StreamStats application takes a user-defined outlet on a stream and delineates the drainage basin of the stream at that location. The basin outlet and delineated basin are used as the templates for estimating basin characteristics. The contributing drainage areas calculated by using StreamStats were compared to previously published drainage areas for those 
streams with gaging stations. The drainage areas were within 2 percent of each other in 95 percent of cases.

Mean-annual precipitation proved to be an influential independent variable in past analyses (Sauer, 1974a; Thomas and Corley, 1977; Tortorelli and Bergman, 1985; Tortorelli, 1997). Mean-annual precipitation data over the drainage basin for the period 1971 to 2000 (PRISM Climate Group, 2008), computed by using an area-weighted method, were used to define a point estimate of mean-annual precipitation for a streamflow gage.

The Oklahoma StreamStats application was used to compute 10-85 channel slope, which is defined as the difference in elevation between points at 10 and 85 percent of the stream length starting from the outlet and along the longest flow path (also referred to as main-channel length). StreamStats computes the longest flow path from the USGS National Hydrography Dataset (NHD) and the corresponding elevations by using a Digital Elevation Model (DEM) from the USGS National Elevation Dataset (NED, U.S. Geological Survey, 2006). The automated slope computation procedures used in StreamStats are similar to the manual computation procedures used by Tortorelli (1997), but generally are more precise because the automated slope computations are performed exclusively on 1:24,000-scale data (Smith and Esralew, U.S. Geological Survey, written commun., 2010) but previous methods used slope computations at different scales. The computed slope is reported in units of feet per mile ( $\mathrm{ft} / \mathrm{mi})$.

\section{Estimate of Magnitude and Frequency of Peak Streamflows at Streamflow- Gaging Stations on Unregulated Streams}

This section describes the procedures applied to estimate peak streamflow at specific frequencies for gaging stations on unregulated streams.

Flood magnitude and frequency can be estimated for a specific gaging station by analysis of peak annual streamflow at that gaging station. These estimates, in the past, have been reported in terms of a T-year flood (for example, 100-year flood) based on the recurrence interval for that flood. The terminology associated with flood-frequency estimates has shifted away from the T-year recurrence interval flood to the P-percent chance exceedance flood. T-year recurrence intervals with corresponding annual exceedance probabilities and P-percent chance exceedances are shown in table 3. Throughout the remaining sections of this report the P-percent chance exceedance terminology will be used to describe peak-streamflow frequency estimates.

\section{Peak Streamflow Frequency}

The IACWD provides a standard procedure for peakstreamflow frequency estimate, U.S. Geological Survey Bulletin $17 \mathrm{~B}$, that involves a standard frequency distribution, the log-Pearson Type III (LPIII) (Interagency Advisory Committee on Water Data, 1982). Systematically collected and historic peak streamflows are fit to the LPIII distribution. The asymmetry in the shape of the distribution is defined by a skew coefficient that is used in the estimate procedure. Estimates of the P-percent chance exceedance flows can be computed by the following equation:

$$
\log \mathrm{Q}_{\mathrm{x}}=\mathrm{X}+\mathrm{KS}
$$

where

$$
\begin{aligned}
& \mathrm{Q}_{\mathrm{x}} \quad \begin{array}{l}
\text { is the P-percent chance exceedance flow, in } \\
\text { cubic feet per second; }
\end{array} \\
& \mathrm{X} \quad \text { is the mean of the logarithms of the annual } \\
& \text { peak flows; } \\
& \mathrm{K} \quad \text { is a factor based on the skew coefficient and } \\
& \text { the given percent chance exceedance, } \\
& \text { which can be obtained from appendix } 3 \text { in } \\
& \text { U.S. Geological Survey Bulletin 17B; and } \\
& \mathrm{S} \quad \text { is the standard deviation of the logarithms } \\
& \text { (base 10) of the annual peak-streamflows } \\
& \text { that is a measure of the degree of variation } \\
& \text { of the annual log of peak-streamflow about } \\
& \text { the mean log peak-streamflow. }
\end{aligned}
$$

Because of variation in the climatic and physiographic characteristics in Oklahoma and the bordering areas, the LPIII distribution does not always adequately define a suitable distribution of peak-streamflow values (Tortorelli, 1997). To reduce errors in peak-streamflow frequency resulting from a poor LPIII fit, estimates of peak-streamflow frequency for the streamflow-gaging stations evaluated in this report were adjusted based on historic flood information (where available), low-outlier thresholds, and skew coefficients, and IACWD guidelines.

The USGS computer program PEAKFQWin version 5.2.0 was used to compute flood-frequency estimates for the 231 streamflow-gaging stations on unregulated streams evaluated in this report. PEAKFQWin automates many of the analytical procedures recommended in U.S. Geological Survey Bulletin 17B (Interagency Advisory Committee on Water Data, 1982). The PEAKFQWin program and associated documentation can be downloaded from the Web at http:/ water.usgs.gov/software/PeakFQ. Peak-streamflow frequency estimates of the 50-, 20-, 10-, 4-, 2-, 1-, and 0.2-percent chance exceedances are given in table 1 for each streamflowgaging station used in this report. 


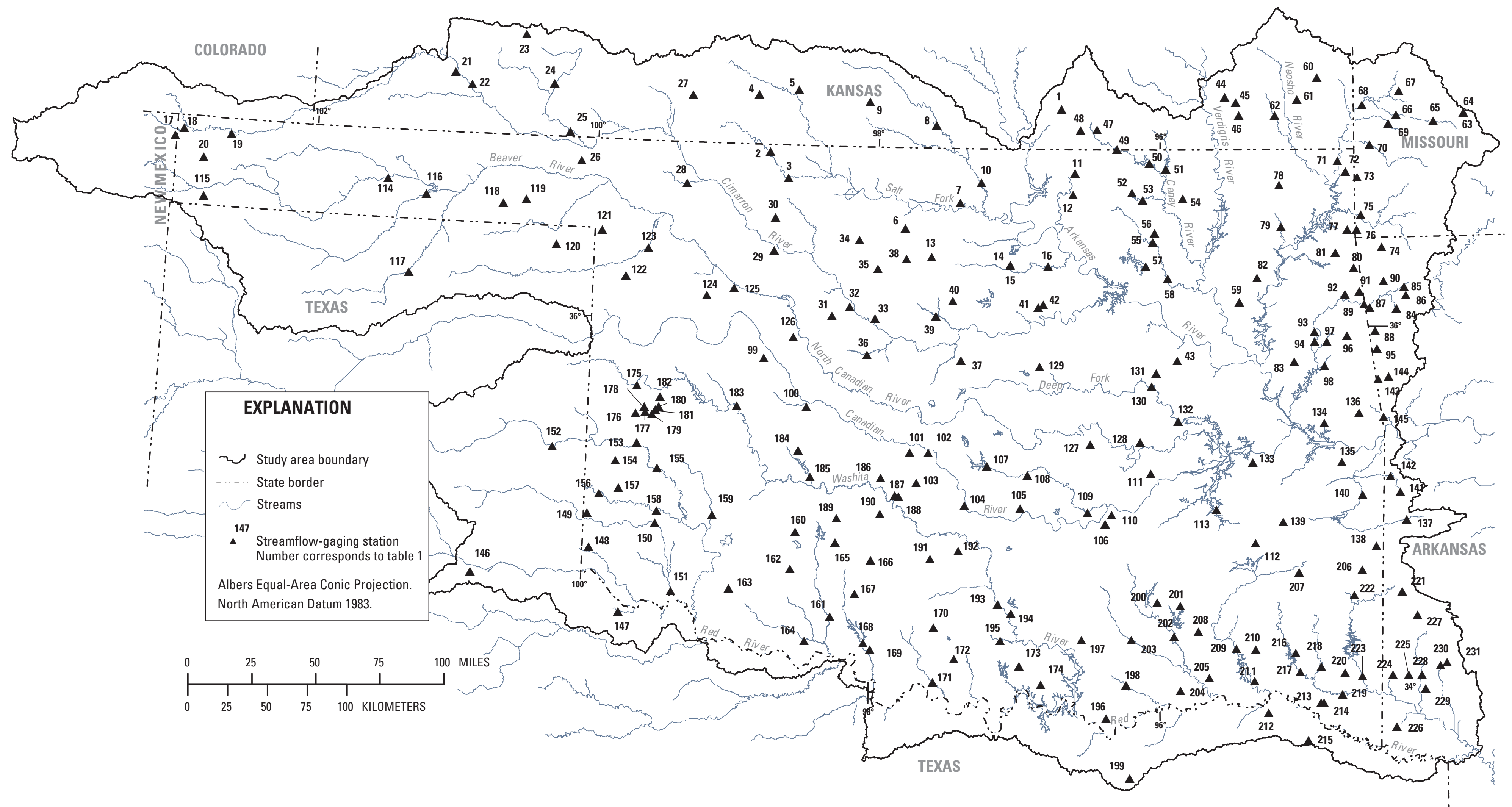

Figure 1. Location of streamflow-gaging stations with unregulated periods of record used in report. 


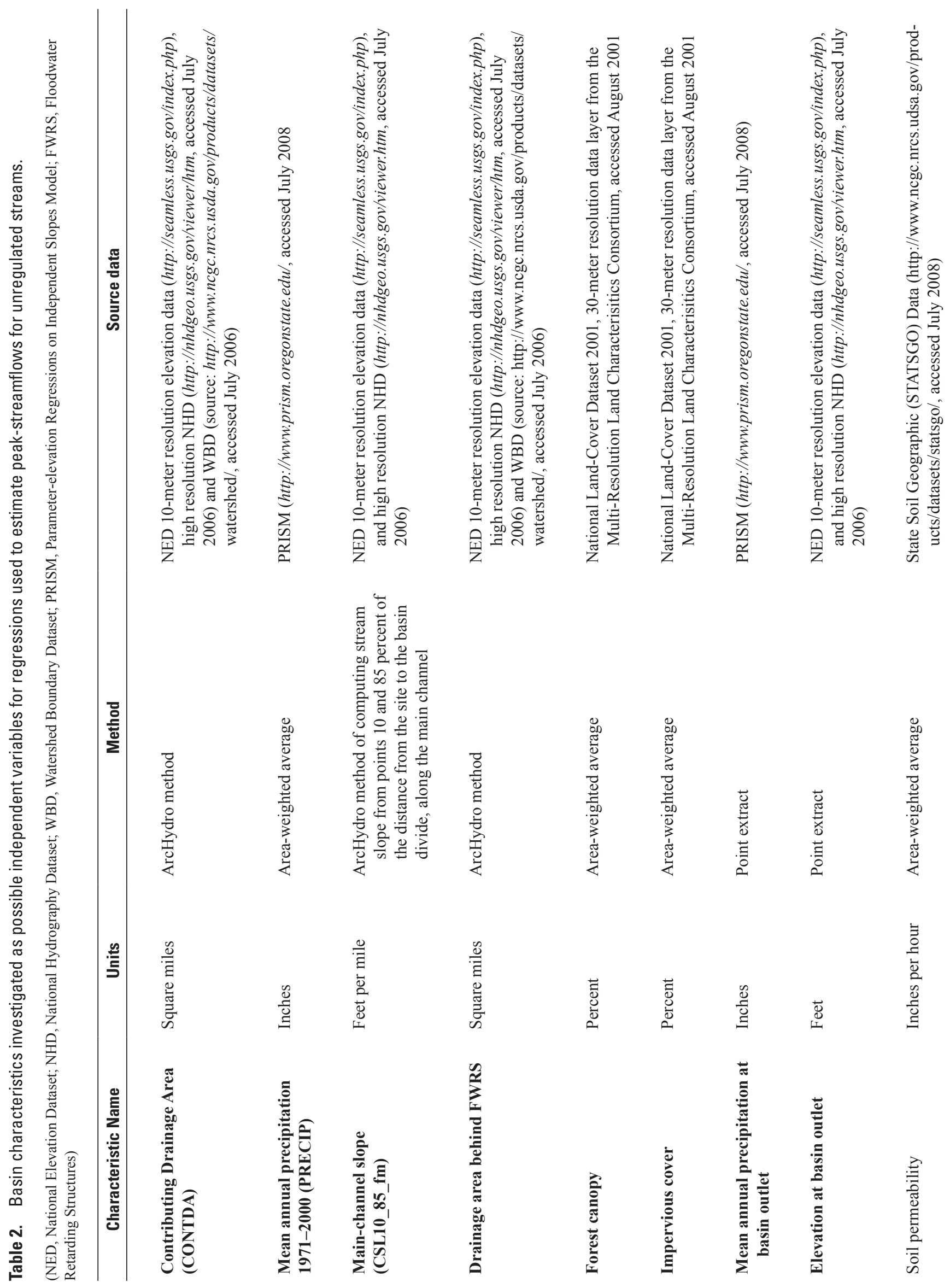




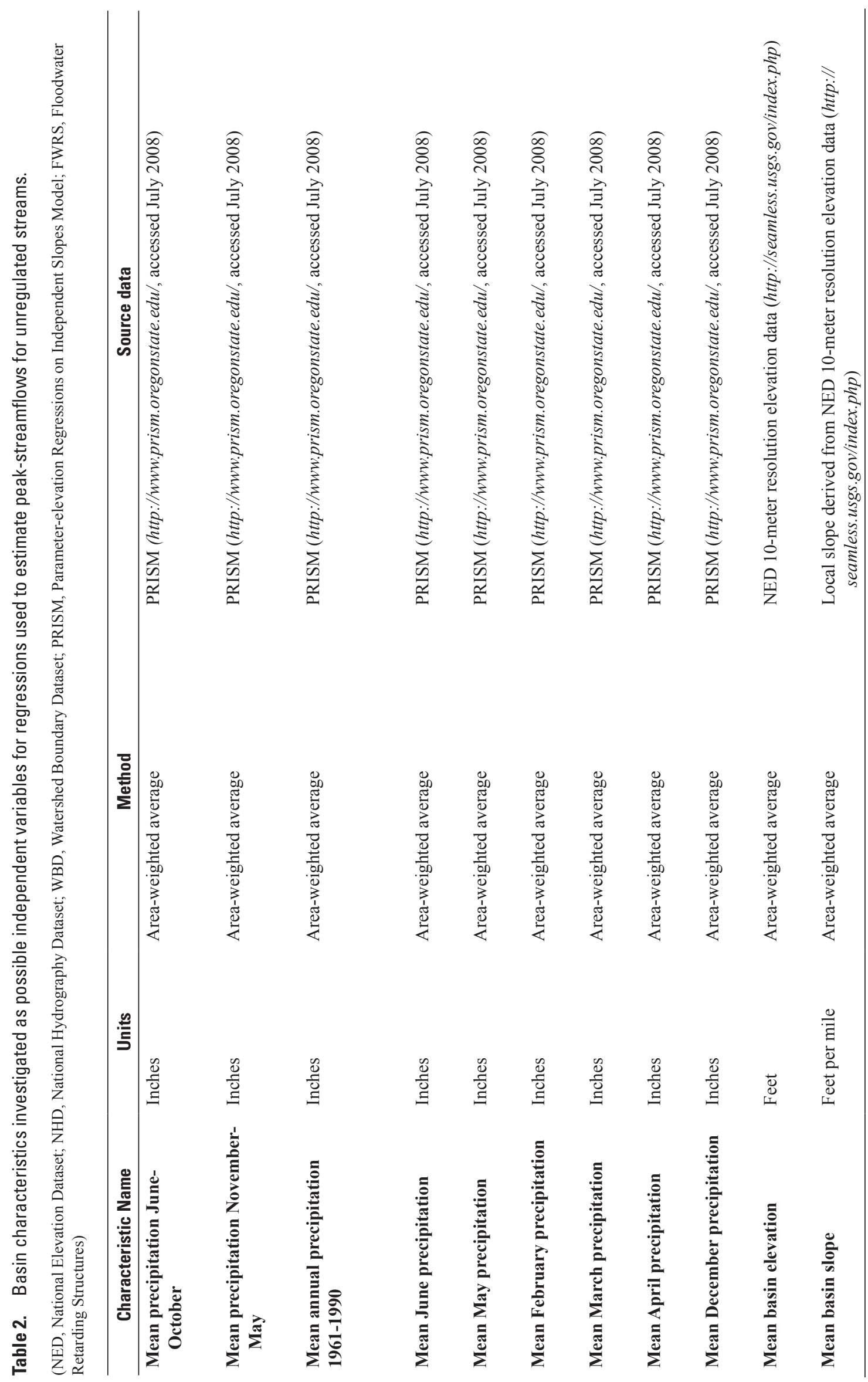


Table 3. T-year recurrence intervals with corresponding annual exceedance probabilities and P-percent chance exceedances for peak-streamflow frequency estimates.

\begin{tabular}{ccc}
\hline $\begin{array}{c}\text { T-year recurrence } \\
\text { interval }\end{array}$ & $\begin{array}{c}\text { Annual exceed- } \\
\text { ance probability }\end{array}$ & $\begin{array}{c}\text { P-percent chance } \\
\text { exceedance }\end{array}$ \\
\hline & & \\
2 & 0.5 & 50 \\
5 & 0.2 & 20 \\
10 & 0.1 & 10 \\
25 & 0.04 & 4 \\
50 & 0.02 & 2 \\
100 & 0.01 & 1 \\
500 & 0.002 & 0.2 \\
\hline
\end{tabular}

\section{Low-Outlier Thresholds}

Determining low-outlier thresholds are necessary in peak-streamflow frequency analyses because of the fact that these low outliers have a strong influence on the skew coefficient. Past flood frequency analyses for Oklahoma have shown that extremely small annual peak-streamflow discharges (low outliers) occasionally happen. The effects of low outliers can been seen visually by fitting the LPIII distribution, but the U.S. Geological Survey Bulletin 17B method specifies a mathematical low-outlier threshold based on skew and standard deviation of the peak-streamflow time series. The fit of the LPIII distribution to the data needs to adjusted to account for low outliers because these outliers can substantially affect the distribution curve. All peak-streamflow discharges (including zero) below the threshold are excluded from the fitting of the LPIII distribution. The computer program PEAKFQWin was used to identify these low outliers.

PEAKFQWin, which incorporates the IACWD guidelines, provides a procedure for low-outlier threshold selection based on a 90-percent confidence interval for a standard distribution. However, the IACWD procedure may not always produce appropriate low-outlier thresholds for streamflow-gaging stations. Therefore, the preliminary LPIII distribution for each streamflow-gaging station was then visually inspected and some streamflow-gaging stations were assigned a low-outlier threshold based on that inspection. The low-outlier thresholds for appropriate streamflow-gaging stations are listed in table 1 .

\section{Weighted Skew}

Determining skew coefficients is the next step in peakstreamflow frequency analyses. The skew coefficient measures the asymmetry of the probability distribution of a set of annual peaks and is difficult to estimate reliably for streamflowgaging stations with short periods of record. Therefore, the IACWD recommends applying a weighted skew coefficient to the LPIII distribution. This skew coefficient is calculated by weighting the skew coefficient computed from the peakstreamflow data at the gaging station (station skew) and a generalized skew coefficient representative of the surrounding area (fig. 2). The weighted skew coefficient is based on the inverse of the respective mean square errors for each of the two skew coefficients (Interagency Advisory Committee on Water Data, 1982).

The weighted skew coefficient generally is preferred for peak-streamflow frequency estimates. The station skew and weighted skew are listed in table 1 (back of report) for each gaging station. Weighted skew coefficients (station skews weighted with generalized skews from Lewis and Esralew, (2009)) were used for all streamflow-gaging stations in this report.

\section{Generalized-Skew Analysis}

A nationwide generalized-skew map is provided in U.S. Geological Survey Bulletin 17B (Interagency Advisory Committee on Water Data, 1982). However, a more accurate generalized skew map was needed for Oklahoma instead of a map prepared at a national scale. Previously, a report of generalized skew coefficients was done for Oklahoma (Lewis and Esralew, 2009) that used adjusted station skew coefficients from streamflow-gaging stations with at least 20 years of peak-streamflow data and drainage basins greater than $10 \mathrm{mi}^{2}$ and less than 2,510 $\mathrm{mi}^{2}$ with streamflow data through 2007.

The generalized skew map for Oklahoma was created in GIS by using a point interpolation (pointintrp) method and contour smoothing functions (Lewis and Esralew, 2009). The streamflow-gaging stations used to develop the Oklahoma generalized skew map are noted in table 1 with footnote 7 . The generalized skew values for all streamflow-gaging stations were obtained by using GIS.

\section{Estimate of Magnitude and Frequency of Peak Streamflows at Ungaged Sites on Unregulated Streams}

Estimates of magnitude and frequency of peak streamflows commonly are needed at ungaged sites. These estimates can be achieved by defining regression equations that relate peak discharges of selected frequencies at streamflow-gaging stations to basin characteristics. Multiple-linear regression analysis was used to establish the statistical relations between one dependent variable (peak streamflow) and one or more independent variables (basin characteristics). The 50-, 20-, 10-, 4-, 2-, 1-, and 0.2-percent chance exceedance flows, respectively, were used as dependent variables, and the selected basin characteristics were used as independent variables. Logarithmic transformations of the dependent and independent variables were used to increase the linearity between 
the dependent and independent variables. The general steps followed in this report to develop regression equations are:

1. Basin characteristics were screened to identify possible explanatory variables used in the regression equations.

2. Peak-streamflow percent chance exceedance flows and basin characteristics were log transformed to obtain better linear relations between the dependent variables and the independent variables.

3. Stepwise regression analysis was used to assess the most appropriate basin characteristics.

4. Preliminary multiple linear regression models were formed by using ordinary least squares (OLS).

5. Residual plots were examined, and leverage and influence statistics were computed and plotted to identify data observations that may substantially influence regression results. Outliers were removed based on this procedure.

6. Iterations of steps $2-5$ were completed, for OLS regression models, in an attempt to reduce the number of independent variables.

7. Weighting procedures were developed.

8. Significance of coefficients in the weighted least squares (WLS) regression model was checked along with residuals, and streamflow-gaging stations with large leverage and influence were identified.

9. From the same dataset, a generalized least squares (GLS) regression model was formed by using the USGS computer program weighted-multiple-linear regression WREG v.1 (Eng and others, 2009).

OLS regression analysis was performed on streamflow data from the 231 streamflow-gaging stations to determine if regression equations for separate hydrologic regions in the state was warranted. A similar check was performed on the GLS models. No geographic patterns were evident after the residuals (differences between estimated peak streamflow and measured peak streamflow) were examined (fig. 3).

\section{Regression Analysis}

Previous regression analysis of peak-streamflow frequency for Oklahoma (Tortorelli, 1997) used WLS procedures. In this report OLS, WLS, and GLS regression procedures were used. WLS regression was used to test the statistical significance $(p<0.05)$ of possible independent variables (Ries and Dillow, 2006). The GLS method was then used to determine the final regression equations. Stedinger and Tasker (1985) showed that the GLS method can be used to assign weights to the streamflow-gaging station data used in the regression analysis to adjust not only for differences in record length, as in WLS, but also for cross-correlation of the annual time series on which the peak-flow statistics for the gaging station data are based, and for spatial correlation among the gaging station data. Annual peak flows of basins are cross-correlated because a single storm can cause the annual peak in several basins. One advantage of using GLS is that cross-correlation among basins is taken into account.

GLS regression entails weighting each basin in accordance with the variance (time-sampling error) and spatialcorrelation structure of the streamflow characteristic (annual peak-discharge among streamflow-gaging stations) (Lumia and others, 2006). The residual mean square error for ungaged sites is portioned into regression model error (error in assuming an incomplete regression form) and sampling error (timeand spatial-sampling errors). When using GLS, the variance of prediction (and the square root, the standard error of prediction) is the sum of the model error variance and an additional term. This additional term has been called a sampling error variance (of the coefficients), but is different from the timesampling and spatial-sampling error.

The GLS regression analysis used in this report incorporated logarithmic (base 10) transformations of the streamflow (annual peak discharges) and basin characteristics to obtain a constant variance of the residuals about the regression line, and to make the relation between the dependent variable (peak-discharge) and independent variables (basin characteristics) acceptable for linear least-squares regression procedures. The multiple-regression equations based on logarithmic transformation of the variables has the following form:

$\log _{10} Y=b_{0}+b_{1} \log _{10} X+b_{2} \log _{10} X+\ldots \ldots+b_{\mathrm{n}} \log _{10} X_{\mathrm{n}}$

and the following form after taking antilogs,

$$
\mathrm{Y}=10^{\mathrm{b} 0}\left(\mathrm{X}_{1}^{\mathrm{b} 1}\right)\left(\mathrm{X}_{2}^{\mathrm{b} 2}\right) \ldots \ldots\left(\mathrm{X}_{\mathrm{n}}^{\mathrm{bn}}\right)
$$

where

$$
\begin{aligned}
& \mathrm{Y}= \begin{array}{c}
\text { dependent variable (peak-discharge for } \\
\text { selected exceedance) }
\end{array} \\
& b_{\mathrm{o}} \text { to } b_{\mathrm{n}}=\begin{array}{c}
\text { regression model coefficient estimate } \\
\text { by using GLS procedures, and }
\end{array} \\
& X_{1} \text { to } X_{\mathrm{n}}=\begin{array}{c}
\text { independent variables (basin } \\
\text { characteristics). }
\end{array}
\end{aligned}
$$

The USGS computer program WREG applying OLS, WLS, and GLS approaches was used to estimate the regression parameters (Eng and others, 2009). WREG allows for selection between the three approaches and also for transformations on the dependent and independent variables. The multiple performance metrics from the WREG program were used to identify possible problem sites used in the regression. The residuals metric is used to show differences between estimated and measured flow at various flow magnitudes. Residuals randomly distributed around zero are preferred. The leverage metric is used to measure how distant the values of 


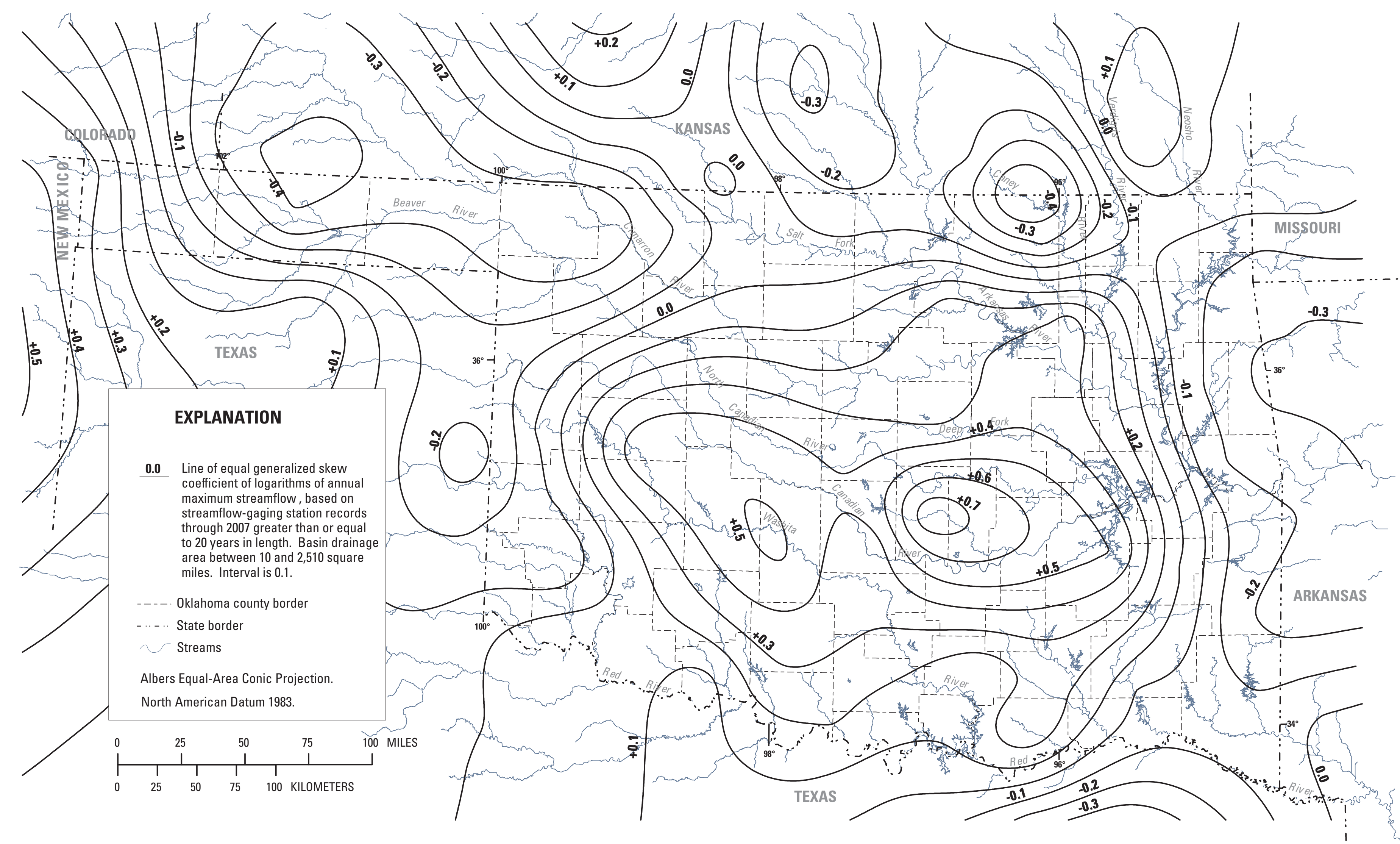

Figure 2. Generalized skew coefficients of logarithms of annual maximum streamflow for Oklahoma streams with drainage area less than than or equal to 2,510 square miles. 
12 Methods for Estimating the Magnitude and Frequency of Peak Streamflows for Unregulated Streams in Oklahoma 


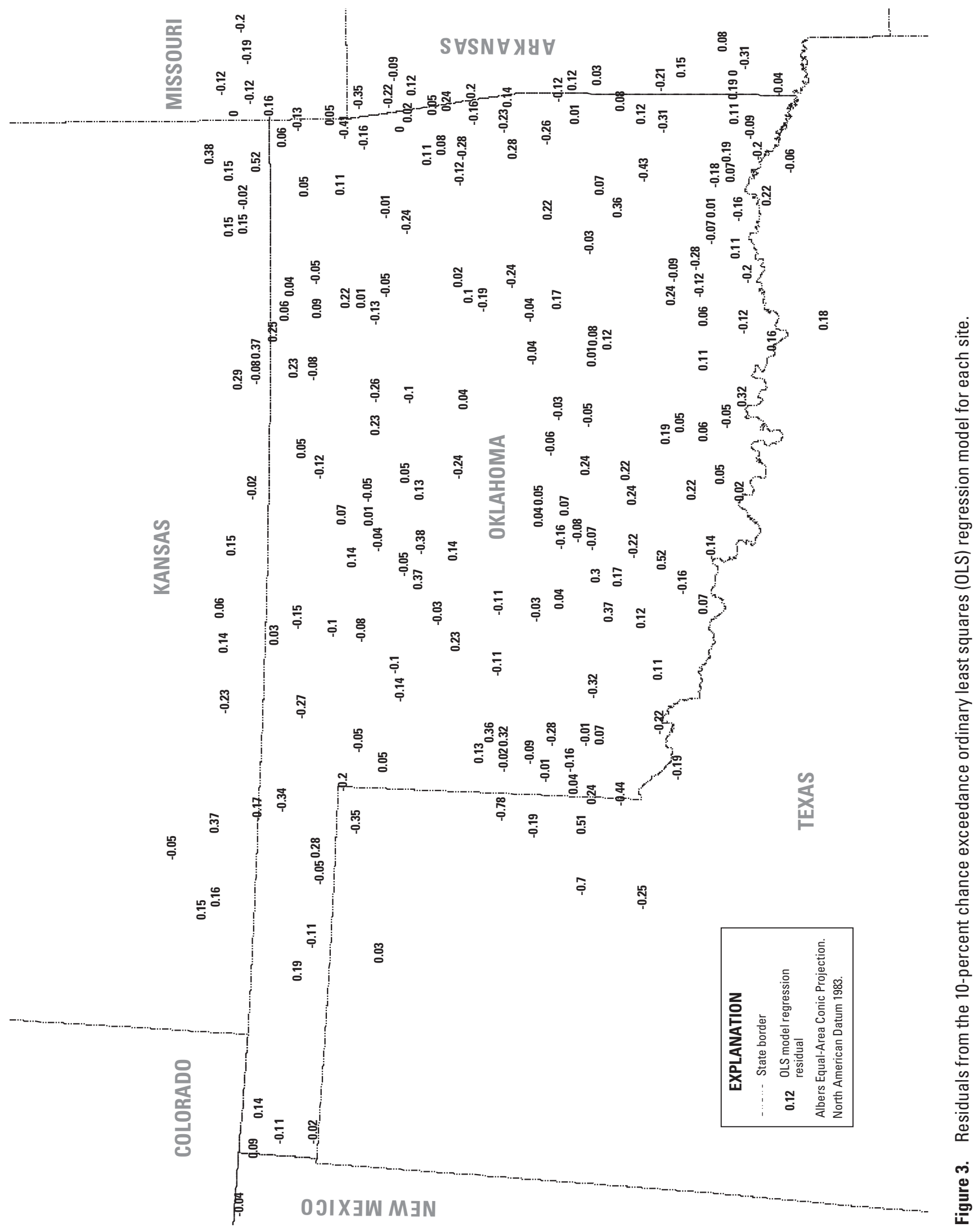


A.

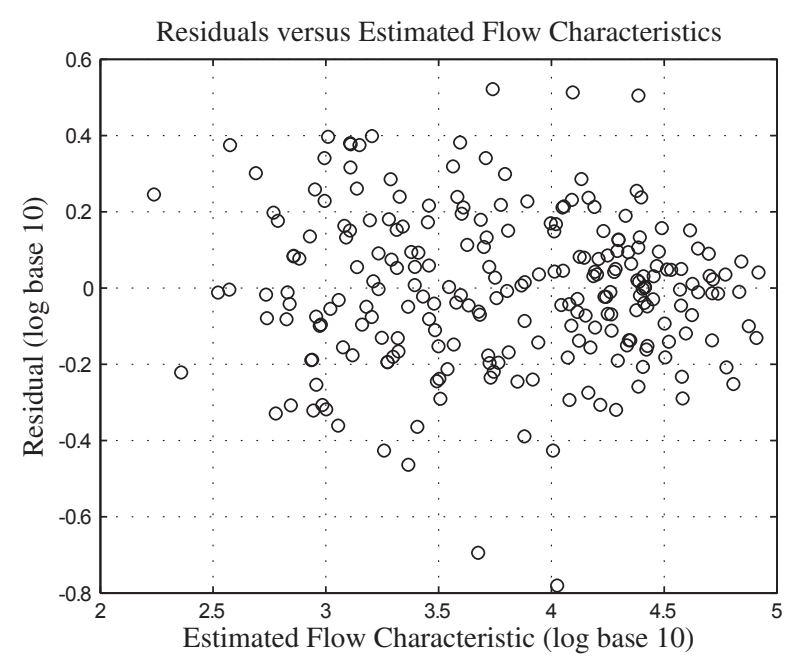

B.

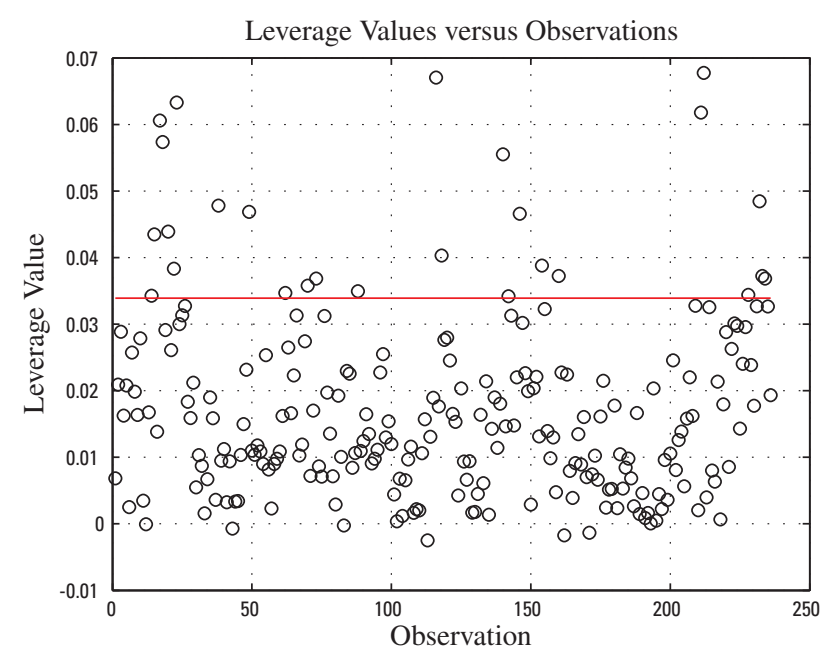

C.

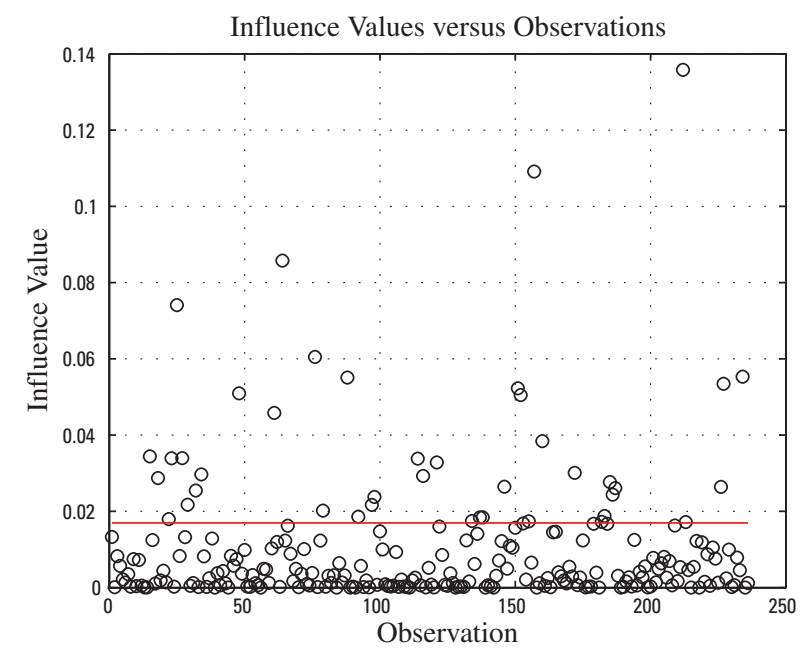

Figure 4. Performance metrics from computer program WREG (A) residuals, (B) leverage, and (C) influence for a 10-percent chance exceedance peak-streamflow regression model. independent variables at one streamflow-gaging station are from the centroid of values of the same variables at all other streamflow-gaging stations. The influence metric indicates whether a streamflow-gaging station had a large influence on the estimated regression parameter values (Eng and others, 2009). Streamflow-gaging stations, identified as having large influence and leverage, were not necessarily removed because the gaging station may have been the only gaging station in a particular area or because removal did not alter the regression. After examining the leverage and influence plots, the following sites were removed: Dry Cimarron River near Guy, New Mexico, (07153500), Fly Creek near Faulkner, Kansas, (07184600), Lelia Lake Creek below Bell Creek near Hedley, Texas, (07299890), Salt Fork Red River near Wellington, Texas, (07300000), and Sweetwater Creek near Kelton, Texas, (07301410). Caution is needed when estimating peak streamflows in areas near the streamflow-gaging stations listed because of irrigation practices. The final performance metrics for the 10-percent chance exceedance regression model are shown in figure 4.

\section{Regression Equations}

Regression equations were developed for use in estimating peak streamflows associated with 50-, 20-, 10-, 4-, 2-, 1-, and 0.2-percent chance exceedances. Combinations of independent variables that did not have substantially large leverage or influence, and multicollinearity that also provided the lowest estimated error for each percent exceedance, were selected for inclusion in the final regression equations. Contributing drainage area, mean-annual precipitation, and main-channel slope were the most appropriate basin characteristics used to estimate peak-streamflow frequency on unregulated streams. The three characteristics used in the regression equations are listed in table 1 for each streamflow-gaging station used in the analysis.

The following equations were computed for unregulated streams from the results of the GLS regression analysis in WREG and are listed according to percent chance exceedance.

$$
\begin{aligned}
& Q_{50 \%}=0.064(\text { CONTDA })^{0.66}(\text { PRECIP })^{2.06}(\text { CSL10_85fm })^{0.16} \\
& Q_{20 \%}=0.574(\text { CONTDA })^{0.66}(\text { PRECIP })^{1.63}(\text { CSL10_85fm })^{0.19} \\
& Q_{10 \%}=1.74(\text { CONTDA })^{0.66}(\text { PRECIP })^{1.42}(\text { CSL10_85fm })^{0.21} \\
& Q_{4 \%}=4.90(\text { CONTDA })^{0.66}(\text { PRECIP })^{1.24}\left(\text { CSL } 10 \_85 f m\right)^{0.23}
\end{aligned}
$$

$$
Q_{2 \%}=13.18(\text { CONTDA })^{0.66}(\text { PRECIP })^{1.05}\left(C S L 10 \_85 f m\right)^{0.21}
$$




$$
\begin{aligned}
& Q_{1 \%}=26.9(\text { CONTD } A)^{0.65}(\text { PRECIP })^{0.92}\left(\text { CSL } 10 \_85 f m\right)^{0.21} \\
& Q_{0.2 \%}=126(\text { CONTDA })^{0.64}(\text { PRECIP })^{0.64}(\text { CSL10_85fm })^{0.19}
\end{aligned}
$$

where

$Q_{50 \%,}, Q_{20 \%}, \ldots \ldots$, and $Q_{0.2 \%}=$ the peakstreamflows with percent chance exceedances of 50 percent, 20 percent, ......, and 0.2 percent, in cubic feet per second;

CONTDA= the contributing drainage area, in square miles;

PRECIP mean-annual precipitation, the point mean-annual precipitation from the period 1971-2000;

CSL10_85fm = the main-channel slope, measured at the points that are 10 percent and 85 percent upstream from the station or ungaged site, on the main-channel length between the study site and the drainage divide, in feet per mile.

\section{Accuracy and Limitations}

Regression equations are statistical models in which the results are inexact. Regression equations needs to be applied within the limits of the data with the understanding that the results are best-fit estimates with associated variances. Three measures that can be used to assess the accuracy of a regression peak-discharge estimate are: the adjusted coefficient of determination $\left(\mathrm{R}^{2}\right)$, the average standard error of prediction, and the standard model error.

Residual errors in the model (differences between estimated and measured values) are examined to determine variables that optimize the accuracy of a regression equation, which depends on the model and sampling error. Model errors represent errors that result from an incomplete model. These errors are described by the standard model error. Sampling errors result from the limitations on the number of years of streamflow-gaging station record, the assumption of gaging station record being representative of long-term streamflow, and from hydrologic conditions during the particular period represented by samples. Although the use of GLS methodology allows separation of the sampling error variance from the total mean square error of the residuals, the GLS methodology does not prevent this type of error.

$\mathrm{R}^{2}$ is the proportion of the variability in the dependent variable (site peak discharge, $Q_{\mathrm{x}(\mathrm{s})}$ ) that is accounted for by the independent variables (the basin characteristics, CONTDA, PRECIP, and CSL10_85fm) - the larger the $\mathrm{R}^{2}$ the better the fit of the model — with a value of 1.00 indicating that 100 percent of the variability in the dependent variable is accounted for by the independent variables (Helsel and Hirsch, 2002). Griffis and Stedinger (2007) state that $\mathrm{R}_{\text {pseudo }}^{2}$ is a more appropriate performance metric for WLS and GLS regressions. $\mathrm{R}_{\text {pseudo }}^{2}$ is based on the variability in the dependent variable explained by the regression, after removing the effect of the time-sampling error (Eng and others, 2009). Table 4 lists all $\mathrm{R}_{\text {pseudo }}^{2}$ values for each of the percent exceedance chance peak streamflows.

The standard error of prediction is derived from the sum of the model error variance and the sampling error of the coefficients, and is a measure of the expected accuracy of the regression estimates for the selected percent chance exceedances. The standard model error, which depends on the number and predictive power of the independent variables, measures the ability of these variables to estimate peak-streamflow frequency from the site records that were used to develop the equation. The WREG program reports average standard error of prediction ( $\mathrm{Sp}$ ), standard model error, and $\mathrm{R}_{\text {pseudo }}^{2}$ in the model output (fig. 5). The average standard error of prediction ranges from 32 to 47 percent and the standard model error ranges from 31 to 46 percent for the percent chance exceedances computed (table 4 ).

Equivalent years of record, proposed by Hardison (1971), is another way of measuring the reliability of peak-streamflow regression equations. Equivalent years of record, which is an approximation, is the number of actual years of record needed to provide estimates equal in accuracy to those estimates computed by the regression equations. The accuracy of the regression equations for unregulated streams, expressed as equivalent years, is summarized in table 4.

The regression equations developed in this report are applicable to streams in Oklahoma with drainage areas less than 2,510 $\mathrm{mi}^{2}$ that are not substantially affected by regulation. The equations are intended for use on unregulated streams in Oklahoma and should not be used outside the range of the independent variables used in the analysis:

\begin{tabular}{lcc}
\hline CONTDA & $\begin{array}{c}\text { equal to or greater } \\
\text { than } 0.100 \text { square } \\
\text { mile }\end{array}$ & $\begin{array}{c}\text { and less than or } \\
\text { equal to } 2,510 \\
\text { square miles }\end{array}$ \\
PRECIP & $\begin{array}{l}\text { equal to or greater } \\
\text { than } 16.6 \text { inches }\end{array}$ & $\begin{array}{c}\text { and less than or } \\
\text { equal to } 62.1 \\
\text { inches }\end{array}$ \\
CSL10_85fm & $\begin{array}{l}\text { equal to or greater } \\
\text { than } 1.98 \text { foot per } \\
\text { mile }\end{array}$ & $\begin{array}{c}\text { and less than or } \\
\text { equal to } 342 \text { feet } \\
\text { per mile }\end{array}$ \\
\hline
\end{tabular}

The same cautions are applicable for estimating flows on streams regulated with floodwater retarding structures as with unregulated drainage basin peak-streamflow estimates. The adjusted equations described in "Adjustment for Ungaged Sites on Urban Streams" can be used when the percent of regulated drainage area is not greater than 86 percent of the basin, which is the upper limit of the range of regulated data used to check the validity of the adjustment (Tortorelli, 1997; 
Table 4. Accuracy of peak-streamflows estimated for unregulated streams in Oklahoma.

$\left[\mathrm{R}^{2}\right.$; coefficient of determination; \%, percent $]$

\begin{tabular}{cccc}
\hline $\begin{array}{c}\text { Percent } \\
\text { chance } \\
\text { exceedance }\end{array}$ & $\begin{array}{c}\mathbf{R}^{2} \\
\text { pseudo }\end{array}$ & $\begin{array}{c}\mathbf{S}_{\mathbf{p}} \text { (average } \\
\text { standard error } \\
\text { of prediction, } \\
\text { in \%) }\end{array}$ & $\begin{array}{c}\text { Standard } \\
\text { model } \\
\text { error (\%) }\end{array}$ \\
\hline & & & \\
50 & 92.36 & 46.74 & 45.89 \\
20 & 94.98 & 35.11 & 34.26 \\
10 & 95.70 & 31.80 & 30.88 \\
4 & 94.88 & 34.66 & 32.98 \\
2 & 94.98 & 33.98 & 32.86 \\
1 & 94.51 & 35.72 & 34.52 \\
0.2 & 92.36 & 43.26 & 41.87 \\
\hline
\end{tabular}

Tortorelli and Bergman, 1985). The adjusted equations are intended for use on parts of a basin with NRCS floodwater retarding structures and not with any other floodwater retarding structures. When the regulated drainage area is greater than 86 percent of the basin, the flow routing techniques in Chow and others (1988) may be used.

\section{Application of Methods}

This section presents methods for use of the regression equations to make a weighted peak-streamflow estimate for streamflow-gaging station data on unregulated streams with a drainage area less than 2,510 $\mathrm{mi}^{2}$ in Oklahoma, and to use this result to make an estimate for a nearby ungaged site on the same stream. For ungaged sites on urban streams and ungaged sites on streams regulated by floodwater retarding structures, an adjustment of the statewide regression equations for unregulated stream can be used to estimate peak-streamflow frequency.

\section{Estimate for a Streamflow-Gaging Station}

Interagency Advisory Committee on Water Data (1982) recommends that peak-streamflow frequency estimates for streamflow-gaging station sites on unregulated streams are combinations of streamflow-gaging station data and regression estimates. The estimates weighted by years of record are considered to be more reliable than either the regression estimate or gaging-station data when making estimates of peak-streamflow frequency relations at gaging-station sites (Sauer, 1974a; Thomas and Corley, 1977). The equivalent years of record concept is used to combine gaging-station estimates with regression estimates to obtain weighted estimates of peakstreamflow at a gaging station site.
The locations of the streamflow-gaging stations with unregulated periods of record used in the report are shown in figure 1. Figure 1 is used to obtain the gaging-station number of the gaging station of interest. This number is used to obtain the appropriate station peak-streamflow $\left(\mathbf{Q}_{\mathrm{x}(\mathrm{s})}\right)$, for percent chance exceedance $\mathbf{x}$, from table 1 . The streamflow-gaging stations that have unregulated periods of record, but are now regulated, are noted with footnote 8 in table 1 . If the gaging station of interest is still unregulated, then this peak-streamflow is used with the regression estimate $\mathbf{Q}_{\mathrm{x}(\mathrm{r})}$ in a weighting procedure described by Sauer (1974a) and Thomas and Corley (1977):

$$
\mathbf{Q}_{\mathrm{x}(\mathrm{w})}=\left[\mathbf{Q}_{\mathrm{x}(\mathrm{s})}(\mathbf{N})+\mathbf{Q}_{\mathrm{x}(\mathrm{r})}(\mathbf{E})\right] /(\mathbf{N}+\mathbf{E})
$$

where

$$
\begin{aligned}
& \mathbf{Q}_{\mathrm{x}(\mathrm{w})}=\text { the weighted estimate of peak } \\
& \mathbf{Q}_{\mathrm{x}(\mathrm{s})}=\text { the gaging station estimate of peak } \\
& \mathbf{Q}_{\mathrm{x}(\mathrm{r})}=\text { the regression estimate of peak }
\end{aligned}
$$

\section{Example}

The following example illustrates how the method described is used to determine weighted peak-streamflow estimates for a streamflow-gaging station on an unregulated stream. The example computation is for Kiamichi River near Big Cedar, Okla., (07335700) and the results are presented in table 5 .

The column $\mathbf{Q}_{\mathbf{x}(\mathbf{s})}$ in table 5 indicates the computed peakstreamflow frequency relations derived from the 43 years of record (column N) at gaging station 07335700 (site 206, table $1)$. The values in the column labeled $\mathbf{Q}_{\mathbf{x}(\mathbf{r})}$ were estimated by using equations 4-10 and the following basin characteristics (table 1):

$$
\begin{aligned}
\text { CONTDA } & =39.6 \text { square miles } \\
\text { PRECIP } & =62.1 \text { inches } \\
\text { CSL10_85fm } & =54.9 \text { feet per mile }
\end{aligned}
$$

The $\mathbf{Q}_{\mathbf{x}(\mathbf{r})}$ estimates computed from equations 4-10 are presented in table 5. The weighted estimates, $\mathbf{Q}_{\mathbf{x}(\mathbf{w})}$ were computed from equation 11 by using appropriate years of $\mathbf{E}$ from table 5 . 


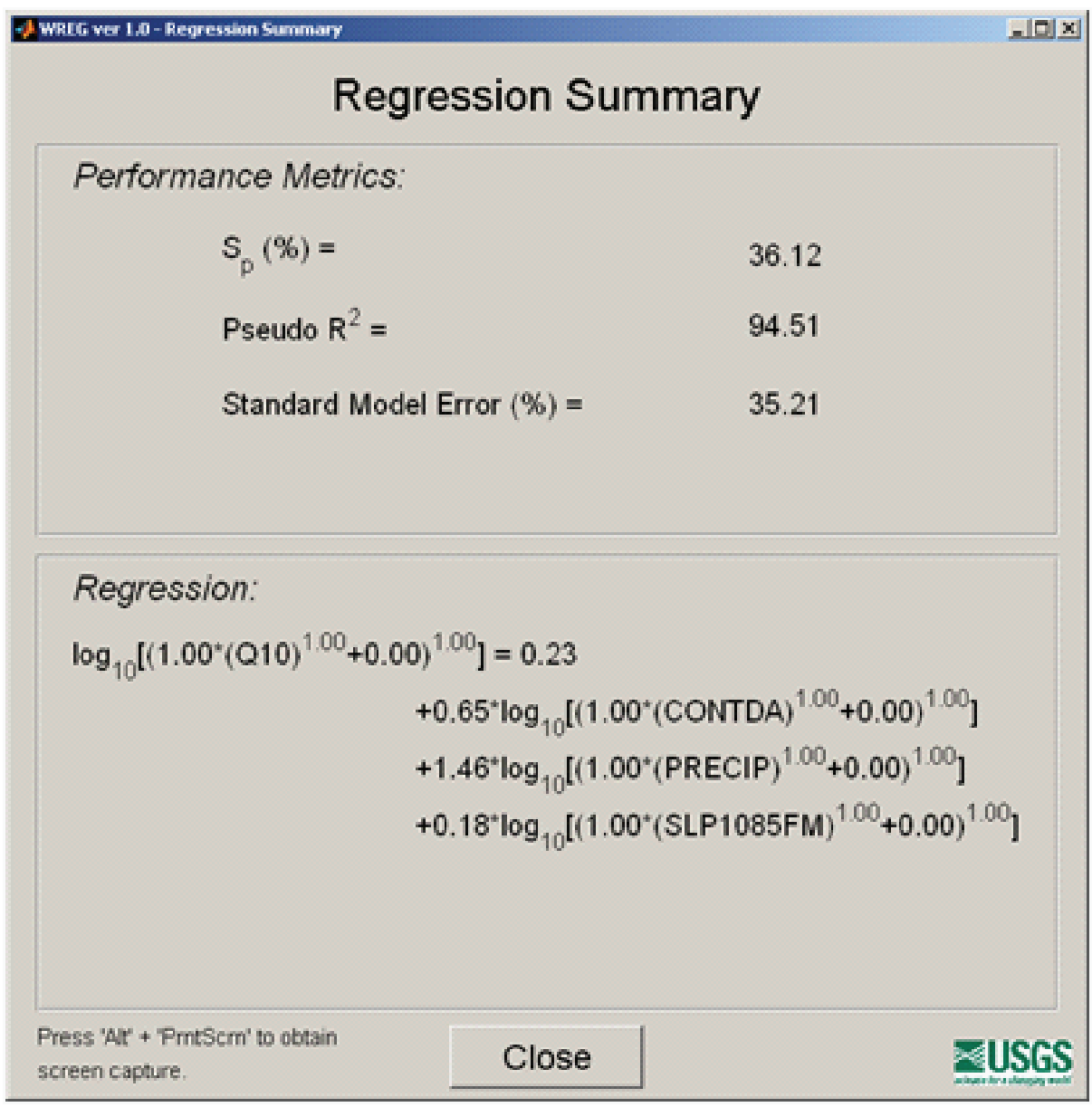

Figure 5. WREG output for the 10-percent chance exceedance peakstreamflow regression model by using the generalized least squares (GLS) method, showing average standard error of prediction (Sp \%), the pseudo coefficient of determination (Pseudo $R_{2}$ ), and standard model error, in percent (\%). SPL1085FM is CSL10_85fm (main-channel slope), CONTDA is contributing drainage area, and PRECIP is mean-annual precipitation used in regression equations (4-10).

Table 5. Weighted peak-streamflow frequency estimates for Kiamichi River near Big Cedar, Oklahoma (07335700)

[ft $\mathrm{ft}^{3} / \mathrm{s}$, cubic feet per second; $\%$, percent]

\begin{tabular}{|c|c|c|c|c|c|}
\hline $\begin{array}{l}\text { Percent chance } \\
\text { exceedance }(\%)\end{array}$ & $\begin{array}{c}\mathbf{0}_{\mathrm{x}(\mathrm{s})}{ }^{1} \\
\left(\mathrm{ft}^{3} / \mathrm{s}\right)\end{array}$ & $\begin{array}{c}\mathrm{N}^{2} \\
\text { (years) }\end{array}$ & $\begin{array}{c}\mathbf{0}_{x(r)}{ }^{3} \\
\left(\mathrm{ft}^{3} / \mathrm{s}\right)\end{array}$ & $\begin{array}{c}E^{4} \\
\text { (years) }\end{array}$ & $\begin{array}{c}\mathbf{0}_{x(w)}{ }^{5} \\
\left(\mathrm{ft}^{3} / \mathbf{s}\right)\end{array}$ \\
\hline 50 & 9,200 & 43 & 6,800 & 2 & 9,090 \\
\hline 20 & 15,100 & 43 & 11,700 & 5 & 14,700 \\
\hline 10 & 19,300 & 43 & 16,100 & 8 & 18,800 \\
\hline 4 & 24,800 & 43 & 23,300 & 9 & 24,500 \\
\hline 2 & 29,000 & 43 & 26,400 & 11 & 28,500 \\
\hline 1 & 33,300 & 43 & 30,400 & 12 & 32,700 \\
\hline 0.2 & 43,400 & 43 & 39,900 & 12 & 42,600 \\
\hline
\end{tabular}

${ }^{1}$ Station estimate of peak discharge, for percent chance exceedance $\mathrm{x}$, table 1 .

${ }^{2}$ Number of actual years of streamflow record at streamflow-gaging station, table 1.

${ }^{3}$ Regression estimate of peak discharge, for percent chance exceedance $\mathrm{x}$, equations 4-10.

${ }^{4}$ Equivalent years of unregulated streamflow record for percent chance exceedance $\mathrm{x}$, table 4 .

${ }^{5}$ Weighted estimate of peak discharge, for percent chance exceedance $\mathrm{x}$, equation 11. 


\section{Estimate for an Ungaged Site near a Streamflow-Gaging Station}

The combined use of the regression equations and the gaging-station data can yield an estimate of the peakstreamflow magnitude and frequency for ungaged sites near streamflow-gaging stations on the same stream. The following method is indicated for use if the ungaged site has a drainage area within 50 percent of the drainage area of the gaging station (Sauer, 1974a). The ratio, $\mathbf{R}_{\mathrm{w}}$, represents the correction needed to adjust the regression estimate, $\mathbf{Q}_{\mathrm{x}(\mathrm{r})}$, to the weighted estimate, $\mathbf{Q}_{\mathrm{x}(\mathrm{w})}$, at the streamflow-gaging station:

$$
R_{w}=\frac{Q_{x(w)}}{Q_{x(r)}}
$$

where

$$
\begin{aligned}
& \mathbf{Q}_{\mathrm{x}(\mathrm{w})} \text { is the weighted estimate of peak } \\
& \text { streamflow at the gaging-station } \\
& \text { site, for percent chance exceedance } \\
& \mathbf{x} \text { (equation 11), in cubic feet per } \\
& \text { second, and } \\
& \mathbf{Q}_{\mathrm{x}(\mathrm{r})} \text { is the regression estimate of peak } \\
& \text { streamflow at the gaging-station } \\
& \text { site, for percent chance exceedance } \\
& \mathbf{x} \text { (equations 4-10), in cubic feet } \\
& \text { per second. } \\
& \mathbf{R}_{\mathrm{w}} \text { is then used to determine the correction } \\
& \text { factor } \mathbf{R}_{\mathrm{c}} \text { for the ungaged site. } \\
& \text { The following equation derived } \\
& \text { by Sauer (1974a) gives the } \\
& \text { correction factor } \mathbf{R}_{\mathrm{c}} \text {, for an ungaged } \\
& \text { site that is near a gaging-station site } \\
& \text { on the same stream, }
\end{aligned}
$$$$
\mathrm{R}_{c}=R_{w}-\frac{\Delta C O N T D A}{0.5 C O N T D A_{g}}\left(R_{w} 1.00\right)
$$

where

$$
\begin{aligned}
& \triangle \text { CONTDA is the difference between the } \\
& \text { drainage areas of the } \\
& \text { gaging-station site and } \\
& \text { ungaged site, and }
\end{aligned}
$$

The regression estimate, $\mathbf{Q}_{\mathrm{x}(\mathrm{r})}$ for the ungaged site is multiplied by the correction factor $\mathbf{R}_{\mathrm{c}}$ to improve the estimate by using nearby gaging-station data. If the drainage area of the ungaged site is within 50 percent of two gaging-station sites, the peak-streamflow frequency estimate for the ungaged site can be made by interpolation of the weighted station peakstreamflow $\left(\mathbf{Q}_{\mathrm{x}(\mathrm{w})}\right)$ for each gaging-station site. Interpolation is on the basis of drainage area. If the peak streamflows for the ungaged site are affected by urbanization, the peak streamflows need to be modified by methods given in the following section “Adjustment for Ungaged Sites on Urban Streams". If the drainage area of the ungaged site is 50 percent more than or less than that of the gaging-station site (that is, $\triangle$ CONTDA/ CONTDA $_{g}$ is greater than 0.5), equation 11 is not used and the regression equations $4-10$ are used without adjustment.

\section{Example}

The following example illustrates how to adjust a weighted estimate calculated for a streamflow-gaging-station site on an unregulated stream for an ungaged site on the same stream. Assume an estimate of the 1 percent chance exceedance flood is needed at an ungaged site upstream from gaging station 07335700 on the Kiamichi River (table 5). Assume the following hypothetical basin characteristics:

$$
\begin{array}{ll}
\text { CONTDA } & =20.5 \text { square miles } \\
\text { PRECIP } & =54.0 \text { inches } \\
\text { CSL10_85fm } & =42.0 \text { feet per mile }
\end{array}
$$

The following data and calculations are needed to estimate $Q_{1 \%}$ at the ungaged site. Cedar

Gaging station site, 07335700, Kiamichi River near Big

$$
\begin{array}{lrl}
\text { CONTDA }_{\mathrm{g}}= & 39.6 \text { square miles } \\
\mathbf{Q}_{1 \%(\mathrm{r})} & =30,400 \text { cubic feet per second, } \\
& \text { from equation } 9, \text { table } 5 \\
\mathbf{Q}_{1 \%(\mathrm{w})} & =32,700 \text { cubic feet per second, } \\
& \text { from equation } 11 \text {, table } 5 \\
\mathbf{R}_{\mathrm{w}} & =\mathbf{Q}_{1 \%(\mathrm{w})} / \mathbf{Q}_{1 \%(\mathrm{r})}=1.08
\end{array}
$$

Ungaged site on Kiamichi River

$$
\begin{array}{cc}
\text { CONTDA } & =20.5 \text { square miles } \\
\mathbf{Q}_{1 \%(\mathrm{r})} & =16,500 \text { cubic feet per second, from } \\
\Delta \text { CONTDA }=19.1 & \text { equation } 9 \\
\text { square miles } \\
\Delta \text { CONTDA/CONTDA } A_{\mathrm{g}}=0.48 \text { (Because } 0.48 \text { is less than } \\
& 0.5, \mathbf{R}_{\mathrm{c}} \text { is computed from } \\
& \text { equation } 12 \text { and used to adjust } \\
\left.\mathbf{Q}_{1 \%(\mathrm{r})}\right)
\end{array}
$$

$$
R_{c}=108-\frac{19.1}{0.5(39.6)}(1.08-1.00)=1.00
$$

$$
\mathbf{Q}_{1 \%}=\mathbf{Q}_{1 \%(r)}\left(\mathbf{R}_{\mathrm{c}}\right)=\underset{\text { second }}{16,500(1.00)=16,500 \text { cubic feet per }}
$$

The estimate of the 1 percent chance exceedance flood at the ungaged site on the Kiamichi River is a discharge of 
$16,500 \mathrm{ft}^{3} / \mathrm{s}$, after the regression estimate is adjusted for the data for gaging station 07335700 .

\section{Adjustment for Ungaged Sites on Urban Streams}

The percentage of the basin that is impervious and the percentage of the basin served by storm sewers is required in addition to the variables needed for ungaged sites on unregulated streams to estimate flood magnitude and frequency for ungaged sites on urban streams. The percentage of the basin that is impervious can be determined from the StreamStats web application, aerial photographs, recent USGS topographic maps, or field surveys. The percentage of the basin served by storm sewers needs to be determined from the best available storm sewer and drainage map.

After the percentages of the area impervious and area served by storm sewers are obtained, $\mathbf{R}_{\mathrm{L}}$, the urban adjustment factor, is obtained from figure 6 (Leopold, 1968).

The urban adjustment factor, $\mathbf{R}_{\mathrm{L}}$, is the ratio of the mean annual flood in urban areas to that in rural areas. The following equations computed by Sauer (1974b) can be used to adjust estimates from equations $4-10$ to urban areas:

$$
\begin{aligned}
& Q_{50 \%(\mathrm{u})}=\mathrm{R}_{\mathrm{L}} \mathrm{Q}_{50 \%(\mathrm{r})} \\
& Q_{20 \%(\mathrm{u})}=1.60\left(\mathrm{R}_{\mathrm{L}}-1\right) \mathrm{Q}_{50 \%(\mathrm{r})}+0.167\left(7-\mathrm{R}_{\mathrm{L}}\right) \mathrm{Q}_{20 \%(\mathrm{r})} \\
& Q_{10 \%(\mathrm{u})}=1.87\left(\mathrm{R}_{\mathrm{L}}-1\right) \mathrm{Q}_{50 \%(\mathrm{r})}+0.167\left(7-\mathrm{R}_{\mathrm{L}}\right) \mathrm{Q}_{10 \%(\mathrm{r})} \\
& Q_{4 \%(\mathrm{u})}=2.21\left(\mathrm{R}_{\mathrm{L}}-1\right) \mathrm{Q}_{50 \%(\mathrm{r})}+0.167\left(7-\mathrm{R}_{\mathrm{L}}\right) \mathrm{Q}_{4 \%(\mathrm{r})} \\
& Q_{2 \%(\mathrm{u})}=2.46\left(\mathrm{R}_{\mathrm{L}}-1\right) \mathrm{Q}_{50 \%(\mathrm{r})}+0.167\left(7-\mathrm{R}_{\mathrm{L}}\right) \mathrm{Q}_{2 \%(\mathrm{r})} \\
& Q_{1 \%(\mathrm{u})}=2.72\left(\mathrm{R}_{\mathrm{L}}-1\right) \mathrm{Q}_{50 \%(\mathrm{r})}+0.167\left(7-\mathrm{R}_{\mathrm{L}}\right) \mathrm{Q}_{1 \%(\mathrm{r})} \\
& Q_{0.2 \%(\mathrm{u})}=3.30\left(\mathrm{R}_{\mathrm{L}}-1\right) \mathrm{Q}_{50 \%(\mathrm{r})}+0.167\left(7-\mathrm{R}_{\mathrm{L}}\right) \mathrm{Q}_{0.2 \%(\mathrm{r})}
\end{aligned}
$$

where

$$
\begin{gathered}
\mathbf{Q}_{\mathrm{x}(\mathrm{u})}=\begin{array}{c}
\text { the adjusted regression estimate of } \\
\text { peak discharge for ungaged sites } \\
\text { on urban streams, for percent } \\
\text { chance exceedance } \mathbf{x} \text {, in cubic feet } \\
\text { per second, }
\end{array} \\
\mathbf{R}_{\mathrm{L}}=\text { urban adjustment factor (fig. 6), and } \\
\mathbf{Q}_{\mathrm{x}(\mathrm{r})}=\text { the regression estimate of peak } \\
\text { discharge for ungaged sites on } \\
\text { unregulated streams, for percent } \\
\text { chance exceedance } \mathbf{x} \text { (equations } \\
\text { 4-10), in cubic feet per second. }
\end{gathered}
$$

A nationwide seven-parameter urban adjustment equation set is presented in Jennings and others (1994). These equations may be compared to or used instead of the Oklahoma equations.

\section{Example}

This example shows how the 1 percent chance exceedance flood can be calculated for a hypothetical stream in an urban environment. The calculation is based on the basin being 50 percent impervious and that 65 percent of the basin is served by storm sewers. The 1 percent chance exceedance flood $\left(\mathrm{Q}_{1 \%(\mathrm{u})}\right)$ can be estimated for this hypothetical urban site with the following additional basin characteristic values:

$$
\begin{aligned}
\text { CONTDA }= & 25.0 \text { square miles } \\
\text { PRECIP }= & 33.0 \text { inches } \\
\text { CSL10_85fm }= & 11.5 \text { feet per mile } \\
& \\
\mathrm{Q}_{1 \%(\mathrm{r})}= & 9,080 \text { cubic feet per second, from } \\
& \quad \text { equation } 9 \text { (rural areas) } \\
\mathrm{Q}_{50 \%(\mathrm{r})}= & 1,060 \text { cubic feet per second, from } \\
& \quad \text { equation } 4 \text { (rural areas) } \\
\mathbf{R}_{\mathrm{L}}= & 3.0, \text { from figure } 6 \\
\mathrm{Q}_{1 \%(\mathrm{u})}= & 11,800 \text { cubic feet per second, from } \\
& \text { equation } 19 \text { (urban areas) }
\end{aligned}
$$

The estimate of the 1 percent chance exceedance flood in urban areas for this ungaged watershed is a discharge of $11,800 \mathrm{ft}^{3} / \mathrm{s}$. This estimate is an increase of 33 percent more than the 1 percent chance exceedance flood for rural areas.

\section{Adjustment for Ungaged Sites on Streams Regulated by Floodwater Retarding Structures}

An adjustment needs to be made when estimating peakstreamflow magnitude and frequency in basins regulated by floodwater retarding structures. The regression estimate of peak-streamflow for ungaged sites on regulated streams, or $\mathbf{F}_{\mathrm{x}(\mathrm{r})}$, for percent chance exceedance $\mathbf{x}$, can be computed from equations $4-10$ by substituting the drainage area of the unregulated part of the basin or drainage area downstream from the floodwater retarding structures, DAUNREG, for CONTDA. A complete discussion of the analysis can be found in Tortorelli and Bergman (1985). These authors indicated that the main-channel slope for the entire basin be used to estimate a conservative result (this method will result in a larger peak streamflow than by using main-channel slope downstream from floodwater retarding structures only).

If floodwater retarding structures regulate less than 86 percent of the basin, the following equations are used to adjust the regression estimate of peak-streamflow of ungaged sites on unregulated streams:

$$
\begin{aligned}
& F_{50 \%(r)}=0.064(\text { DUANREG })^{0.66}(\text { PRECIP })^{2.06}\left(C S L 10 \_85 f m\right)^{0.16} \\
& F_{20 \%(r)}=0.574(\text { DUANREG })^{0.66}(\text { PRECIP })^{1.63}\left(C S L 10 \_8 f m\right)^{0.19}
\end{aligned}
$$




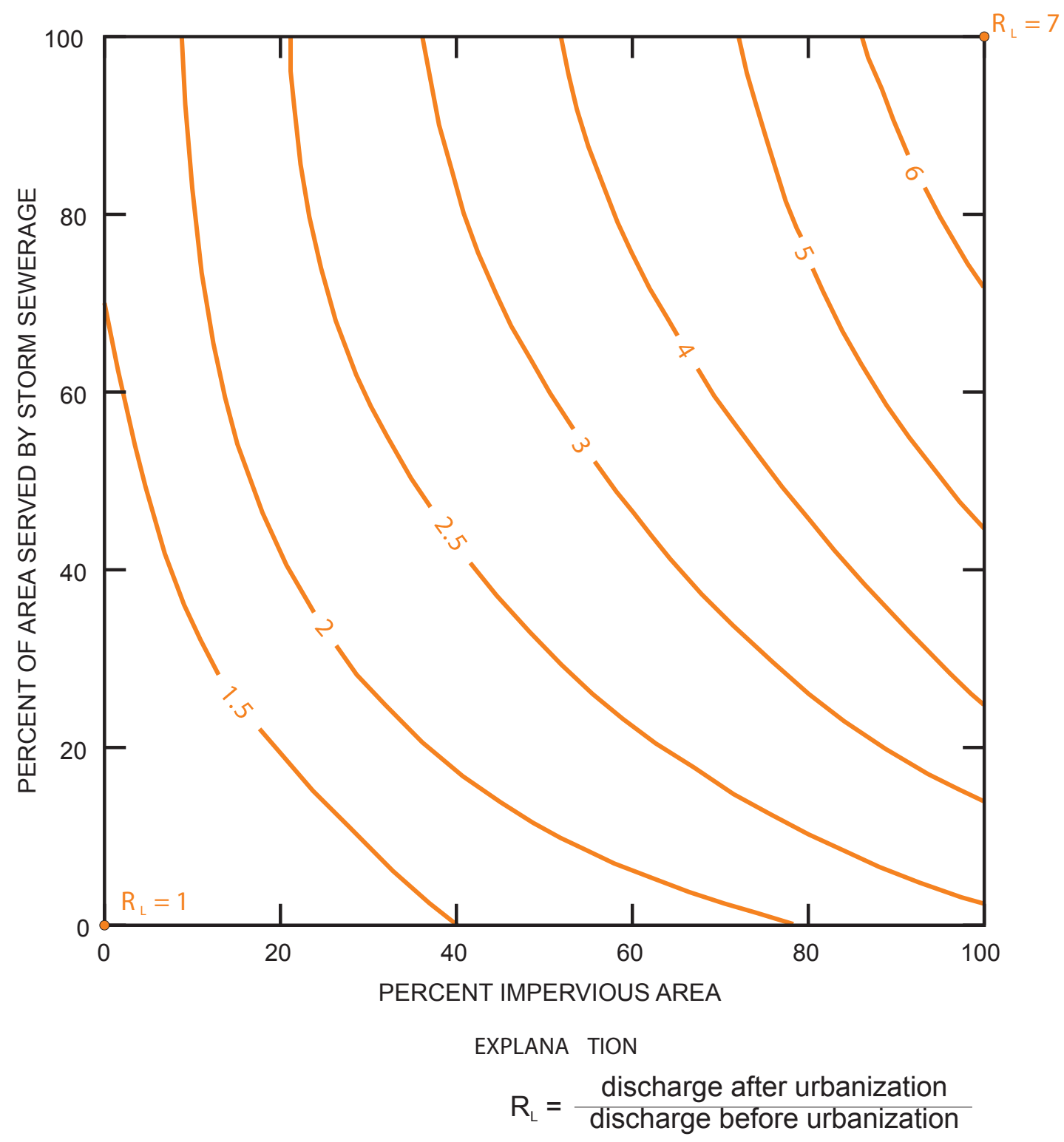

Figure 6. Relation of urban adjustment factor, $\mathrm{R}_{\mathrm{L}^{\prime}}$ to the percentage of area impervious, and served by storm sewer (adapted from Leopold, 1968). 


$$
\begin{aligned}
& F_{10 \%(\mathrm{r})}=1.74(\text { DAUNREG })^{0.66}(\text { PRECIP })^{1.42}\left(C S L 10 \_85 \mathrm{fm}\right)^{0.21} \\
& F_{4 \%(\mathrm{r})}=4.90(D A U N R E G)^{0.66}(P R E C I P)^{1.24}\left(C S L 10 \_85 f m\right)^{0.23} \\
& F_{2 \%(\mathrm{r})}=13.18(D A U N R E G)^{0.66}(\text { PRECIP })^{1.05}\left(C S L 10 \_85 \mathrm{fm}\right)^{0.21} \\
& F_{1 \%(\mathrm{r})}=26.9(D A U N R E G)^{0.65}(P R E C I P)^{0.92}\left(C S L 10 \_85 f m\right)^{0.21}(26) \\
& F_{0.2 \%(\mathrm{r})}=126(\text { DAUNREG })^{0.64}(\text { PRECIP })^{0.64}(\text { CSL10_85fm })^{0.19}
\end{aligned}
$$

where

$$
\begin{aligned}
& \mathbf{F}_{\mathrm{x}(\mathrm{r})}=\text { the regression peak-streamflow estimate } \\
& \text { DAUNREG = the contributing drainage area of the } \\
& \text { unregulated part of the basin or } \\
& \text { drainage area downstream from the } \\
& \text { floodwater retarding structures, in } \\
& \text { square miles, } \\
& \text { PRECIP }=\text { the point mean-annual precipitation at the } \\
& \text { station or ungaged site, for the period } \\
& \text { 1971-2000, in inches, and }
\end{aligned}
$$

The adjusted equations can be used when the percent of regulated drainage area is not greater than 86 percent of the basin, the upper limit of the range of regulated data used to check the validity of the adjustment (Tortorelli and Bergman, 1985). When the percent of regulated drainage area is greater than 86 percent of the basin, flow routing techniques, such as outlined in Chow and others (1988), may be used.

\section{Example}

This example illustrates how a peak-streamflow estimate is calculated for an ungaged site on a stream regulated by floodwater retarding structures. An estimate of the $\mathrm{Q}_{1 \%}$ is needed for this example on an ungaged site on Uncle Johns Creek in Kingfisher County that is regulated by floodwater retarding structures.

To obtain the regression flood-frequency estimate for an ungaged site on a stream regulated by floodwater retarding structures, $\mathbf{F}_{1 \%(\mathrm{r})}$, equation 26 is used. Equation 26 uses DAUNREG, the area of the drainage basin unregulated by floodwater retarding structures, instead of CONTDA. The following data and calculations are needed to estimate $Q_{1 \%}$ for the ungaged site on a stream regulated by floodwater retarding structures:

$$
\begin{array}{ll}
\text { CONTDA } & =155 \text { square miles } \\
\text { DAUNREG } & =65.1 \text { square miles } \\
\text { PRECIP } & =31.0 \text { inches } \\
\text { CSL10_85fm } & =12.0 \text { feet per mile }
\end{array}
$$

The following step is required to obtain the needed peakstreamflow estimate:

$\mathbf{F}_{1 \%(\mathrm{r})}=16,100$ cubic feet per second from equation 26

The estimate of the 1 percent chance exceedance flood with 58 percent of the basin regulated by floodwater retarding structures is a discharge of $16,100 \mathrm{ft}^{3} / \mathrm{s}$.

\section{Summary}

This report presents the results of a cooperative study by the U.S. Geological Survey (USGS) and the Oklahoma Department of Transportation to estimate the magnitude and frequency of peak streamflows from regional regression equations for Oklahoma by using generalized least squares regression methods. Annual-maximum peak flows observed at 231 streamflow-gaging stations through water year 2008 were used for the regression analysis. Gage peak-streamflow estimates were used from previous work unless 2008 gaging-station data were available, in which new peak-streamflow estimates were calculated. The basin characteristics for each site were determined by using a geographical information system and the USGS web application StreamStats. The most statistically significant basin characteristics required to estimate peakstreamflow frequency for unregulated streams in Oklahoma are contributing drainage area, mean-annual precipitation, and main-channel slope. Multiple-regression analyses were used to define the relations between peak-streamflow frequency and basin characteristics. The resulting regression equations can be used to estimate peak discharge and frequency of floods for selected percent chance exceedance floods ranging from 50-0.2 percent.

The regression equations are applicable for basins with a drainage area less than 2,510 square miles that are not substantially affected by regulation. The estimated standard error of prediction for the regression equations ranged from 32 to 47 percent, and standard model error ranged from 31 to 46 percent. This report also presents methods on estimating peak-streamflow magnitude and frequency for ungaged sites on streams with streamflow-gaging stations and for sites on urban streams and streams regulated by floodwater retarding structures. Log-Pearson Type III analysis information, basin characteristics, and the peak-streamflow frequency estimates for 231 streamflow-gaging stations in and near Oklahoma are listed in this report. 


\section{References Cited}

Asquith, W.H., and Slade, R.M., Jr., 1997, Regional equations for estimation of peak-streamflow frequency for natural basins in Texas: U.S. Geological Survey Water-Resources Investigations Report 96-4307, 68 p.

Bergman, D.L., and Huntzinger, T.L., 1981, Rainfall-runoff hydrograph and basin characteristics data for small streams in Oklahoma: U.S. Geological Survey Open-File Report 81-824, $320 \mathrm{p}$.

Chow, V.T., Maidment, D.R., and Mays, L.W., 1988, Applied hydrology: New York, McGraw-Hill, 572 p.

DeCoursey, D.G., 1975, Implications of floodwater-retarding structures: Transactions of the American Society of Agricultural Engineers, v. 18, no. 5, Sept.-Oct. 1975, p. 897-904.

Eng, Ken, Chen, Yin-Yu, and Kiang, J.E., 2009, User's guide to the weighted-multiple-linear-regression program (WREG version 1.0): U.S. Geological Survey Techniques and Methods, book 4, chap. A8, 21 p.

Griffis, V.W., and Stedinger, J.R., 2007, The use of GLS regression in regional hydrologic analyses: Journal of Hydrology, v. 344, p. 82-95.

Hardison, C.H., 1971, Prediction error of regression estimates of streamflow characteristics at ungaged sites, in Geological Survey research 1971, chap. C: U.S. Geological Survey Professional Paper 750-C, p. C228-C236.

Hartman, M.A., Ree, W.O., Schoof, R.R., and Blanchard, B.J., 1967, Hydrologic influences of a flood control program: American Society of Civil Engineers, Journal Hydraulics Division, v. 93, no. 3, May 1967, p. 17-25.

Heimann, D.C., and Tortorelli, R.L., 1988, Statistical summaries of streamflow records in Oklahoma and parts of Arkansas, Missouri, and Texas through 1984: U.S. Geological Survey Water-Resources Investigations Report 87-4205, $387 \mathrm{p}$.

Helsel, D.R., and Hirsch, R.M., 2002. Statistical methods in water resources: U.S. Geological Survey Techniques of Water Resources Investigations, book 4, chap. A3, 522 p.

Interagency Advisory Committee on Water Data, 1982, Guidelines for determining flood flow frequency: Reston, Va., U.S. Geological Survey, Office of Water Data Coordination, Hydrology Subcommittee Bulletin 17B [variously paged].

Jennings, M.E., Thomas, W.O., Jr., and Riggs, H.C., comps., 1994, Nationwide summary of the U.S. Geological Survey regional regression equations for estimating magnitude and frequency of floods for ungaged sites, 1993: U.S. Geological Survey Water-Resources Investigations 94-4002, 196 p.
Leopold, L.B., 1968, Hydrology for urban land planning-A guidebook on the hydrologic effects of urban land use: U.S. Geological Survey Circular 554, $18 \mathrm{p}$.

Lewis, J.M., and Esralew, R.A., 2009, Statistical summaries of streamflow in and near Oklahoma through 2007: U.S. Geological Survey Scientific Investigations Report 2009-5135, $633 \mathrm{p}$.

Lumia, Richard, Freehafer, D.A., and Smith, M.J., 2006, Magnitude and frequency of floods in New York: U.S. Geological Survey Scientific Investigations Report 2006-5112, 152 p.

Moore, C.M., 1969, Effects of small structures on peak flow, in Moore, W.L., and Morgan, C.W., eds., Water Resources Symposium No. 2: Center for Research in Water Resources, University of Texas, Austin, Tex., p. 101-117.

Moore, W.L., and Coskun, Erdal, 1970, Numerical simulation of a watershed as a means to evaluate some effects of floodwater-retarding structures on runoff: Center for Research in Water Resources Technical Report CRWR-45, University of Texas, Austin, Tex., 79 p.

PRISM Climate Group, 2008, Normal annual precipitation grid for the conterminous United States, available online at http://www.prism.oregonstate.edu/state_products/maps. phtml?id=US. (Accessed March 24, 2008).

Ries, K.G., III, and Dillow, J.J.A., 2006, Magnitude and frequency of floods on nontidal streams in Delaware: U.S. Geological Survey Scientific Investigations Report 2006$5146,59 \mathrm{p}$.

Ries, K.G., III, Guthrie, J.G., Rea, A.H., Steeves, P.A., and Stewart, D.W., 2008, StreamStats-A water resources web application: U.S. Geological Survey Fact Sheet 2008-3067, $6 \mathrm{p}$.

Ries, K.G., III, Steeves, P.A., Coles, J.D., Rea, A.H., and Stewart, D.W., 2004, StreamStats-A U.S. Geological Survey web application for stream information: U.S. Geological Survey Fact Sheet 2004-3115, 4 p.

Sauer, V.B., 1974a, Flood characteristics of Oklahoma streams: U.S. Geological Survey Water-Resources Investigations Report 52-73, $301 \mathrm{p}$.

Sauer, V.B., 1974b, An approach to estimating flood frequency for urban areas in Oklahoma: U.S. Geological Survey Water-Resources Investigations Report 23-74, 10 p.

Schoof, R.R., Thomas, W.O., Jr., and Boxley, W.M., 1980, Hydrologic effects of the flood abatement program in southwestern Oklahoma: Water Resources Bulletin, v. 16, no. 2, p. 348-352. 
Smith, S.J., Esralew, R.A., 2010, StreamStats in OklahomaDrainage-basin characteristics and peak-flow frequency statistics for ungaged streams: U.S. Geological Survey Scientific Investigations Report 2009-5255 58 p.

Stedinger, J.R., and Tasker, G.D., 1985, Regional hydrologic analysis, 1 . Ordinary, weighted, and generalized least squares compared: Water Resources Research, v. 21, no. 9, p. $1,421-1,432$.

Tasker, G.D., and Stedinger, J.R.., 1989, An operational GLS model for hydrologic regression: Journal of Hydrology, v. 3 , p. 361-375.

Thomas, W.O., Jr. and Corley, R.K., 1977, Techniques for estimating flood discharges for Oklahoma streams: U.S. Geological Survey Water-Resources Investigations Report 77-54, $170 \mathrm{p}$.
Tortorelli, R.L., 1997, Techniques for estimating peak streamflow frequency for unregulated streams and streams regulated by small floodwater retarding structures in Oklahoma: U.S. Geological Survey Water-Resources Investigations Report 97-4202, 39 p.

Tortorelli, R.L., and Bergman, D.L., 1985, Techniques for estimating flood peak discharges for unregulated streams and streams regulated by small floodwater retarding structures in Oklahoma: U.S. Geological Survey Water-Resources Investigations Report 84-4358, 85 p.

U.S. Geological Survey, 2006, National Elevation Dataset: U.S. Geological Survey, available only online at http://ned. usgs.govt.

U.S. Soil Conservation Service (now Natural Resources Conservation Service), 1972, Hydrology: National Engineering Handbook, Section 4, Washington, D.C., [variously paged]. 


\section{Table 1}


Table 1. Peak-streamflow frequency estimates and basin characteristics for selected stations with at least 8 years of annual

$\left[\mathrm{ft}^{3} / \mathrm{s}\right.$, cubic feet per second; LPIII, Log-Pearson Type III; $\mathrm{mi}^{2}$, square miles; ft/mi, feet per mile; wt, weighted; Trib., Tributary; Ck, creek; Res., Reservoir;

\begin{tabular}{|c|c|c|c|c|c|c|c|}
\hline \multirow[b]{2}{*}{$\begin{array}{c}\text { Site } \\
\text { num- } \\
\text { ber } \\
\text { (fig. 1) }\end{array}$} & \multirow[b]{2}{*}{$\begin{array}{l}\text { Station } \\
\text { number }\end{array}$} & \multirow[b]{2}{*}{ Station name } & \multicolumn{5}{|c|}{ Analysis Information } \\
\hline & & & $\begin{array}{c}\text { Available } \\
\text { systematic } \\
\text { record }^{1} \\
\text { (years) }\end{array}$ & $\begin{array}{l}\text { His- } \\
\text { torical } \\
\text { record } \\
\text { length }{ }^{2} \\
\text { (years) }\end{array}$ & $\begin{array}{c}\text { Number } \\
\text { of high } \\
\text { outliers }\end{array}$ & $\begin{array}{l}\text { High- } \\
\text { outlier } \\
\text { thresh- } \\
\text { old }^{3} \\
\left(\mathrm{ft}^{3} / \mathrm{s}\right)\end{array}$ & $\begin{array}{c}\text { Low- } \\
\text { outlier } \\
\text { thresh- } \\
\text { old }^{4} \\
\left(\mathrm{ft}^{3} / \mathrm{s}\right)\end{array}$ \\
\hline
\end{tabular}

$1 \quad 07148100 \quad$ Grouse Creek near Dexter, Kans. ${ }^{7} \quad 30$

$207148350 \quad$ Salt Fork Arkansas R. nr Winchester, Okla. ${ }^{7} \quad 34$

307148400 Salt Fork Arkansas R. near Alva, Okla. 43

407148700 Dog Creek near Deerhead, Kans. 21

$507148800 \quad$ Medicine Lodge River Trib. nr Medicine Lodge, Kans. ${ }^{7} \quad 21$

$607150580 \quad$ Sand Creek Trib. near Kremlin, Okla. 12

07150870 Salt Fork Arkansas River Trib. near Eddy, Okla.

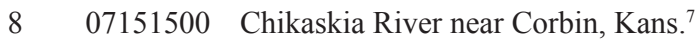

07151600 Rush Creek near Harper, Kans. ${ }^{7}$

07156600 Cimarron River Trib. near Moscow, Kans.

07157100 Crooked Creek near Copeland, Kans. ${ }^{7}$ 
peak-streamflow data from unregulated basins in and near Oklahoma.

L., Little; Lk, Lake; blw, below; SWS, subwatershed; Fk, Fork; R, river; nr, near; \%, percent; SH, State highway; N, north; ab, above]

\begin{tabular}{|c|c|c|c|c|c|c|c|c|c|c|c|c|}
\hline \multicolumn{6}{|c|}{ Basin characteristics } & \multicolumn{7}{|c|}{ Peak-streamflow frequency estimates } \\
\hline $\begin{array}{l}\text { Site } \\
\text { num- } \\
\text { ber } \\
\text { (fig. } \\
\text { 1) }\end{array}$ & Station & Weighted & $\begin{array}{c}\text { Contrib- } \\
\text { uting } \\
\text { drainage } \\
\text { area }\left(\mathrm{mi}^{2}\right)\end{array}$ & $\begin{array}{l}\text { Area-wt } \\
\text { mean } \\
\text { annual } \\
\text { precip- } \\
\text { itation } \\
\text { (inches) }\end{array}$ & $\begin{array}{l}\text { Steam } \\
\text { slope } \\
\text { (ft/mi) }\end{array}$ & 50 & 20 & 10 & 4 & 2 & 1 & 0.02 \\
\hline 2 & -0.390 & -0.118 & 827.23 & 26.4 & 9.40 & 6,640 & 16,100 & 25,200 & 40,400 & 54,600 & 71,200 & 121,000 \\
\hline 3 & -0.513 & -0.306 & 982.09 & 26.7 & 8.43 & 6,520 & 13,300 & 18,800 & 26,700 & 33,100 & 40,000 & 57,600 \\
\hline 4 & -0.145 & -0.066 & 5.05 & 27.1 & 64.44 & 251 & 924 & 1,810 & 3,670 & 5,780 & 8,660 & 19,500 \\
\hline 5 & -0.730 & -0.146 & 2.15 & 28.5 & 38.81 & 143 & 477 & 876 & 1,650 & 2,470 & 3,530 & 7,150 \\
\hline 8 & -0.688 & -0.160 & 812.58 & 30.5 & 7.67 & 9,610 & 18,800 & 26,400 & 37,600 & 46,900 & 57,200 & 84,400 \\
\hline 9 & -1.311 & -0.203 & 11.78 & 31.0 & 20.10 & 1,170 & 2,280 & 3,180 & 4,480 & 5,560 & 6,730 & 9,770 \\
\hline 10 & -0.500 & -0.083 & 1873.05 & 31.8 & 6.58 & 19,200 & 38,000 & 54,100 & 78,300 & 99,200 & 122,000 & 187,000 \\
\hline 11 & -0.648 & -0.127 & 18.34 & 38.7 & 14.65 & 2,230 & 4,590 & 6,630 & 9,750 & 12,400 & 15,500 & 23,800 \\
\hline 12 & -0.014 & -0.140 & 9.06 & 39.2 & 33.19 & 1,640 & 2,100 & 2,380 & 2,700 & 2,940 & 3,160 & 3,650 \\
\hline 13 & -0.083 & 0.087 & 1.02 & 34.7 & 24.01 & 92.5 & 286 & 522 & 1,000 & 1,530 & 2,250 & 4,940 \\
\hline 14 & -1.240 & 0.006 & 0.33 & 37.1 & 52.70 & 134 & 239 & 324 & 447 & 551 & 666 & 975 \\
\hline 20 & -0.005 & 0.253 & 10.70 & 17.1 & 27.54 & 58.2 & 306 & 762 & 2,090 & 4,100 & 7,600 & 27,600 \\
\hline 21 & -1.028 & -0.499 & 21.42 & 18.6 & 23.11 & 459 & 1,400 & 2,360 & 3,920 & 5,310 & 6,870 & 11,000 \\
\hline 22 & -0.357 & -0.370 & 4.23 & 19.3 & 25.88 & 152 & 515 & 924 & 1,660 & 2,380 & 3,240 & 5,820 \\
\hline 23 & -1.203 & -0.257 & 47.74 & 20.3 & 13.09 & 512 & 1,500 & 2,560 & 4,400 & 6,180 & 8,310 & 14,800 \\
\hline 24 & -0.424 & -0.253 & 6.89 & 21.6 & 38.27 & 294 & 1,250 & 2,550 & 5,300 & 8,350 & 12,400 & 27,000 \\
\hline 25 & -1.288 & -0.266 & 821.97 & 21.3 & 3.98 & 3,750 & 7,400 & 10,400 & 14,600 & 18,000 & 21,700 & 31,100 \\
\hline 26 & -0.261 & -0.219 & 4.44 & 22.7 & 55.00 & 108 & 267 & 420 & 667 & 892 & 1,150 & 1,900 \\
\hline 27 & -0.107 & -0.085 & 41.54 & 26.1 & 11.08 & 470 & 1,270 & 2,120 & 3,640 & 5,130 & 6,970 & 12,900 \\
\hline 28 & -0.515 & -0.428 & 401.31 & 25.2 & 11.77 & 1,090 & 4,120 & 7,750 & 14,500 & 21,100 & 29,200 & 53,600 \\
\hline 29 & -0.478 & -0.135 & 4.20 & 28.4 & 28.55 & 534 & 771 & 923 & 1,130 & 1,280 & 1,420 & 1,770 \\
\hline 30 & -0.281 & -0.148 & 1.77 & 28.0 & 57.50 & 151 & 358 & 554 & 874 & 1,160 & 1,500 & 2,490 \\
\hline
\end{tabular}


Table 1. Peak-streamflow frequency estimates and basin characteristics for selected stations with at least 8 years of annual

[ft³/s, cubic feet per second; LPIII, Log-Pearson Type III; mi², square miles; ft/mi, feet per mile; wt, weighted; Trib., Tributary; Ck, creek; Res., Reservoir;

\begin{tabular}{|c|c|c|c|c|c|c|c|}
\hline \multirow[b]{2}{*}{$\begin{array}{c}\text { Site } \\
\text { num- } \\
\text { ber } \\
\text { (fig. 1) }\end{array}$} & \multirow[b]{2}{*}{$\begin{array}{l}\text { Station } \\
\text { number }\end{array}$} & \multirow[b]{2}{*}{ Station name } & \multicolumn{5}{|c|}{ Analysis Information } \\
\hline & & & $\begin{array}{c}\text { Available } \\
\text { systemat- } \\
\text { ic record' } \\
\text { (years) }\end{array}$ & $\begin{array}{l}\text { His- } \\
\text { torical } \\
\text { record } \\
\text { length }{ }^{2} \\
\text { (years) }\end{array}$ & $\begin{array}{c}\text { Number } \\
\text { of high } \\
\text { outliers }\end{array}$ & $\begin{array}{l}\text { High- } \\
\text { outlier } \\
\text { thresh- } \\
\text { old }^{3} \\
\left(\mathrm{ft}^{3} / \mathrm{s}\right)\end{array}$ & $\begin{array}{c}\text { Low- } \\
\text { outlier } \\
\text { thresh- } \\
\text { old } \\
\left(\mathrm{ft}^{3} / \mathrm{s}\right)\end{array}$ \\
\hline 31 & 07158180 & Salt Creek Trib. near Okeene, Okla. & 12 & & & & \\
\hline 32 & 07158400 & Salt Creek near Okeene, Okla. & 12 & & & & \\
\hline 33 & 07158500 & Preacher Creek near Dover, Okla. & 27 & & 1 & 6,000 & \\
\hline 34 & 07158550 & Turkey Creek Trib. near Goltry, Okla. & 19 & & & & \\
\hline 35 & 07159000 & Turkey Creek near Drummond, Okla. ${ }^{7}$ & 27 & 43 & 1 & 30,000 & \\
\hline 36 & 07159200 & Kingfisher Creek near Kingfisher, Okla. & 15 & 40 & & & \\
\hline 37 & 07159810 & Watershed W-VI near Guthrie, Okla. & 14 & & & & \\
\hline 38 & 07160350 & Skeleton Creek at Enid, Okla. & 12 & & & & \\
\hline 39 & 07160500 & Skeleton Creek near Lovell, Okla. ${ }^{7}$ & 51 & 77 & & & \\
\hline 40 & 07160550 & West Beaver Creek near Orlando, Okla. & 22 & & & & \\
\hline 41 & 07163000 & 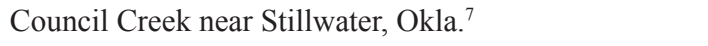 & 60 & 82 & & & \\
\hline 42 & 07163020 & Corral Creek near Yale, Okla. & 12 & & & & \\
\hline 43 & 07165550 & Snake Creek near Bixby, Okla. & 15 & & & & 500 \\
\hline 44 & 07170600 & Cherry Creek near Cherryvale, Kans. & 21 & & 1 & 15,500 & \\
\hline 45 & 07170700 & Big Hill Creek near Cherryvale, Kans. ${ }^{7}$ & 23 & 30 & 1 & 35,000 & \\
\hline 46 & 07170800 & Mud Creek near Mound Valley, Kans. & 34 & & & & 175 \\
\hline 47 & 07171700 & Spring Branch near Cedar Vale, Kans. & 38 & & & & 15 \\
\hline 48 & 07171800 & Cedar Creek Trib. near Hooser, Kans. & 34 & & & & \\
\hline 49 & 07172000 & Caney River near Elgin, Kans. ${ }^{7,8}$ & 26 & & & & \\
\hline 50 & 07173000 & Caney River near Hulah, Okla. ${ }^{8}$ & 12 & & & & \\
\hline 51 & 07174200 & L. Caney River blw Cotton Creek near Copan, Okla. ${ }^{7,8}$ & 21 & & & & \\
\hline 52 & 07174570 & Dry Hollow near Pawhuska, Okla. & 8 & & & & \\
\hline 53 & 07174600 & Sand Creek at Okesa, Okla. ${ }^{7}$ & 34 & & & & \\
\hline 54 & 07174720 & Hogshooter Creek Trib. near Bartlesville, Okla. & 21 & & & & 83 \\
\hline 55 & 07176500 & Bird Creek at Avant, Okla. ${ }^{7,8}$ & 31 & & & & 1,904 \\
\hline 56 & 07176800 & Candy Creek near Wolco, Okla. & 12 & & & & \\
\hline 57 & 07177000 & Hominy Creek near Skiatook, Okla., & 38 & & 1 & 31,100 & 1,498 \\
\hline 58 & 07177500 & Bird Creek near Sperry, Okla. ${ }^{7,8}$ & 46 & & & & 2,186 \\
\hline 59 & 07178640 & Bull Creek near Inola, Okla. & 11 & & & & \\
\hline 60 & 07183800 & Limestone Creek near Beulah, Kans ${ }^{7}$ & 33 & & & & \\
\hline
\end{tabular}


peak-streamflow data from unregulated basins in and near Oklahoma.-Continued

L., Little; Lk, Lake; blw, below; SWS, subwatershed; Fk, Fork; R, river; nr, near; \%, percent; SH, State highway; N, north; ab, above]

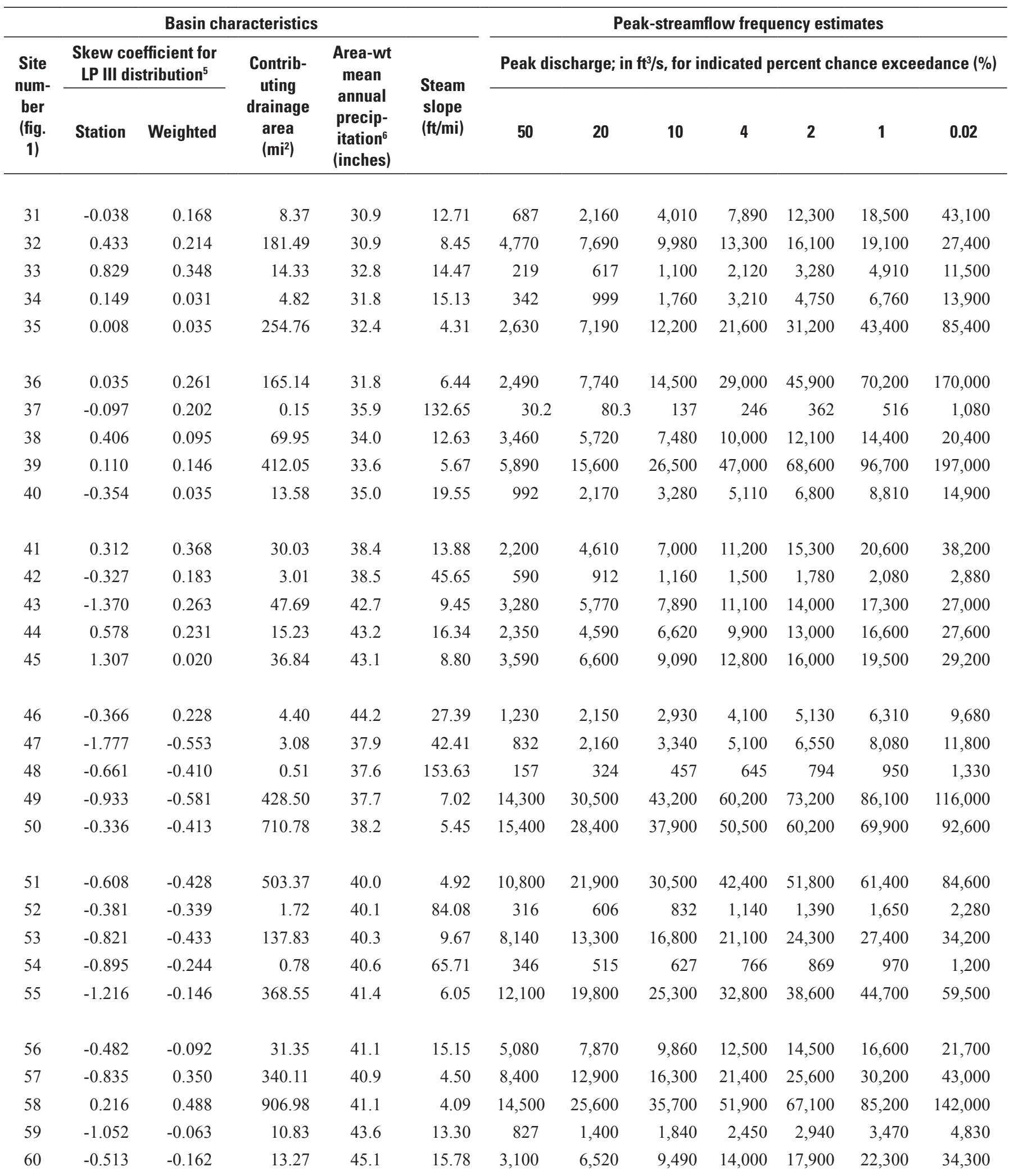


Table 1. Peak-streamflow frequency estimates and basin characteristics for selected stations with at least 8 years of annual

$\left[\mathrm{ft}^{3} / \mathrm{s}\right.$, cubic feet per second; LPIII, Log-Pearson Type III; $\mathrm{mi}^{2}$, square miles; ft/mi, feet per mile; wt, weighted; Trib., Tributary; Ck, creek; Res., Reservoir;

\begin{tabular}{|c|c|c|c|c|c|c|c|}
\hline \multirow[b]{2}{*}{$\begin{array}{l}\text { Site } \\
\text { num- } \\
\text { ber } \\
\text { (fig. 1) }\end{array}$} & \multirow[b]{2}{*}{$\begin{array}{l}\text { Station } \\
\text { number }\end{array}$} & \multirow[b]{2}{*}{ Station name } & \multicolumn{5}{|c|}{ Analysis Information } \\
\hline & & & $\begin{array}{l}\text { Available } \\
\text { systematic } \\
\text { record }^{1} \\
\text { (years) }\end{array}$ & $\begin{array}{l}\text { His- } \\
\text { torical } \\
\text { record } \\
\text { length }{ }^{2} \\
\text { (years) }\end{array}$ & $\begin{array}{c}\text { Number } \\
\text { of high } \\
\text { outliers }\end{array}$ & $\begin{array}{l}\text { High- } \\
\text { outlier } \\
\text { thresh- } \\
\text { old }^{3} \\
\left(\mathrm{ft}^{3} / \mathrm{s}\right)\end{array}$ & $\begin{array}{c}\text { Low- } \\
\text { outlier } \\
\text { thresh- } \\
\text { old } \\
\left(\mathrm{ft}^{3} / \mathrm{s}\right)\end{array}$ \\
\hline 62 & 07184500 & Labette Creek near Oswego, Kans. ${ }^{7}$ & 37 & 56 & & & 1,342 \\
\hline 63 & 07185500 & Stahl Creek near Miller, Mo.7 & 34 & & & & \\
\hline 64 & 07185600 & South Fork Stahl Creek near Miller, Mo. & 28 & & & & \\
\hline 65 & 07185700 & Spring River at LaRussell, Mo. ${ }^{7}$ & 26 & & & & \\
\hline 69 & 07186400 & Center Creek near Carterville, Mo. ${ }^{7}$ & 30 & & & & \\
\hline 70 & 07187000 & Shoal Creek above Joplin, Mo.7 & 85 & & & & \\
\hline 71 & 07188000 & Spring River near Quapaw, Okla.? & 69 & & & & \\
\hline 72 & 07188140 & Flint Branch near Peoria, Okla. & 22 & & & & \\
\hline 73 & 07188500 & Lost Creek at Seneca, Mo. ${ }^{7}$ & 11 & & & & \\
\hline 74 & 07188900 & Butler Creek Trib. near Gravette, Ark. & 21 & & & & 2 \\
\hline 75 & 07189000 & Elk River near Tiff City, Mo. ${ }^{7}$ & 68 & & & & \\
\hline 81 & 07191260 & Brushy Creek near Jay, Okla. & 8 & 10 & 1 & 4,640 & \\
\hline 82 & 07192000 & Pryor Creek near Pryor, Okla. ${ }^{7}$ & 21 & & & & \\
\hline 83 & 07194515 & Mill Creek near Park Hill, Okla. & 20 & & & & 17 \\
\hline 84 & 07194800 & Illinois River at Savoy, Ark. & 13 & & & & \\
\hline 85 & 07195000 & Osage Creek near Elm Springs, Ark.7 & 59 & & & & 508 \\
\hline 86 & 07195200 & Brush Creek Trib. near Tontitown, Ark. & 21 & & & & \\
\hline 87 & 07195430 & Illinois River South of Siloam Springs, Ark. & 13 & & & & 5,811 \\
\hline 88 & 07195450 & Ballard Creek at Summers, Ark. & 24 & & & & \\
\hline 89 & 07195500 & Illinois River near Watts, Okla. ${ }^{7}$ & 53 & & & & \\
\hline 90 & 07195800 & Flint Creek at Springtown, Ark. ${ }^{7}$ & 48 & & & & \\
\hline
\end{tabular}


peak-streamflow data from unregulated basins in and near Oklahoma.-Continued

L., Little; Lk, Lake; blw, below; SWS, subwatershed; Fk, Fork; R, river; nr, near; \%, percent; SH, State highway; N, north; ab, above]

\begin{tabular}{|c|c|c|c|c|c|c|c|c|c|c|c|c|}
\hline \multicolumn{6}{|c|}{ Basin characteristics } & \multicolumn{7}{|c|}{ Peak-streamflow frequency estimates } \\
\hline \multirow{2}{*}{$\begin{array}{c}\text { Site } \\
\text { num- } \\
\text { ber } \\
\text { (fig. } \\
\text { 1) }\end{array}$} & \multicolumn{2}{|c|}{$\begin{array}{l}\text { Skew coefficient for } \\
\text { LP III distribution }\end{array}$} & \multirow{2}{*}{$\begin{array}{l}\text { Contrib- } \\
\text { uting } \\
\text { drainage } \\
\text { area }\left(\mathrm{mi}^{2}\right)\end{array}$} & \multirow{2}{*}{$\begin{array}{c}\text { Area-wt } \\
\text { mean } \\
\text { annual } \\
\text { precip- } \\
\text { itation }^{6} \\
\text { (inches) }\end{array}$} & \multirow{2}{*}{$\begin{array}{l}\text { Steam } \\
\text { slope } \\
\text { (ft/mi) }\end{array}$} & \multicolumn{7}{|c|}{ Peak discharge; in $\mathrm{ft}^{3} / \mathrm{s}$, for indicated percent chance exceedance $(\%)$} \\
\hline & Station & Weighted & & & & 50 & 20 & 10 & 4 & 2 & 1 & 0.02 \\
\hline 61 & 0.462 & 0.216 & 195.94 & 44.8 & 3.43 & 6,760 & 15,300 & 24,000 & 39,200 & 54,400 & 73,300 & 136,000 \\
\hline 62 & -1.189 & -0.055 & 213.21 & 43.0 & 3.71 & 8,160 & 12,900 & 16,300 & 20,800 & 24,400 & 28,200 & 37,500 \\
\hline 63 & -0.554 & -0.197 & 4.02 & 44.9 & 27.03 & 612 & 1,020 & 1,310 & 1,700 & 2,000 & 2,320 & 3,090 \\
\hline 64 & 0.254 & 0.033 & 0.96 & 45.0 & 45.18 & 201 & 392 & 558 & 813 & 1,040 & 1,300 & 2,030 \\
\hline 65 & 0.232 & 0.048 & 305.59 & 45.1 & 6.04 & 5,850 & 11,200 & 15,800 & 22,800 & 28,900 & 35,900 & 55,700 \\
\hline 66 & -0.446 & -0.122 & 447.81 & 45.1 & 5.18 & 7,910 & 17,200 & 25,600 & 38,700 & 50,400 & 63,600 & 101,000 \\
\hline 67 & -0.332 & -0.113 & 9.82 & 45.1 & 11.37 & 1,170 & 1,860 & 2,360 & 3,020 & 3,540 & 4,080 & 5,400 \\
\hline 68 & -0.159 & -0.120 & 1158.12 & 45.1 & 2.51 & 18,800 & 36,000 & 50,000 & 70,600 & 87,900 & 107,000 & 157,000 \\
\hline 69 & 0.526 & 0.115 & 228.93 & 45.1 & 7.75 & 5,430 & 11,000 & 16,100 & 24,200 & 31,700 & 40,500 & 66,900 \\
\hline 70 & 0.028 & -0.011 & 427.45 & 45.6 & 5.83 & 7,260 & 14,610 & 21,040 & 31,020 & 39,850 & 49,910 & 78,660 \\
\hline 71 & -0.084 & -0.080 & 2515.63 & 45.2 & 2.07 & 35,800 & 66,400 & 91,100 & 127,000 & 158,000 & 190,000 & 279,000 \\
\hline 72 & 0.483 & 0.038 & 4.88 & 44.4 & 34.84 & 782 & 1,480 & 2,070 & 2,970 & 3,750 & 4,640 & 7,130 \\
\hline 73 & 0.264 & -0.007 & 40.75 & 45.1 & 22.59 & 892 & 3,220 & 6,290 & 12,800 & 20,400 & 30,800 & 71,200 \\
\hline 74 & -0.956 & -0.359 & 0.99 & 46.9 & 128.02 & 101 & 295 & 494 & 828 & 1,140 & 1,500 & 2,520 \\
\hline 75 & -0.411 & -0.302 & 850.68 & 45.9 & 6.81 & 20,100 & 39,400 & 54,800 & 76,500 & 94,000 & 112,000 & 159,000 \\
\hline 76 & -0.105 & -0.215 & 8.00 & 45.7 & 28.52 & 690 & 1,240 & 1,650 & 2,220 & 2,680 & 3,160 & 4,370 \\
\hline 77 & 0.122 & -0.177 & 48.64 & 46.1 & 23.24 & 1,070 & 2,490 & 3,810 & 5,920 & 7,820 & 10,000 & 16,200 \\
\hline 78 & -1.380 & -0.071 & 71.06 & 43.9 & 9.61 & 4,710 & 8,430 & 11,400 & 15,600 & 19,100 & 22,900 & 32,800 \\
\hline 79 & -0.123 & -0.137 & 450.31 & 44.1 & 4.45 & 16,100 & 28,100 & 37,300 & 50,000 & 60,300 & 71,200 & 98,800 \\
\hline 80 & -0.383 & -0.315 & 131.55 & 47.2 & 14.18 & 3,410 & 9,510 & 15,700 & 26,000 & 35,500 & 46,500 & 78,200 \\
\hline 81 & 1.093 & -0.120 & 16.51 & 46.6 & 26.63 & 854 & 2,170 & 3,490 & 5,740 & 7,880 & 10,400 & 18,200 \\
\hline 82 & 0.193 & 0.017 & 227.41 & 43.5 & 3.71 & 5,300 & 11,700 & 17,800 & 27,800 & 37,200 & 48,200 & 81,700 \\
\hline 83 & -1.584 & -0.228 & 2.10 & 47.0 & 99.43 & 414 & 896 & 1,310 & 1,950 & 2,490 & 3,090 & 4,720 \\
\hline 84 & 0.425 & -0.193 & 167.44 & 48.1 & 13.37 & 11,900 & 20,700 & 27,200 & 36,100 & 43,200 & 50,600 & 69,000 \\
\hline 85 & -0.547 & -0.297 & 129.96 & 47.0 & 15.77 & 5,540 & 10,500 & 14,300 & 19,700 & 23,900 & 28,400 & 39,500 \\
\hline 86 & -0.332 & -0.317 & 0.38 & 46.8 & 127.96 & 68.0 & 177 & 281 & 450 & 601 & 773 & 1,250 \\
\hline 87 & -1.102 & -0.371 & 567.80 & 47.4 & 7.08 & 24,100 & 35,800 & 43,300 & 52,400 & 58,900 & 65,100 & 78,800 \\
\hline 88 & -1.052 & -0.455 & 14.31 & 49.0 & 43.10 & 1,710 & 4,010 & 5,990 & 8,890 & 11,300 & 13,800 & 20,200 \\
\hline 89 & -0.549 & -0.394 & 629.77 & 47.5 & 6.59 & 18,800 & 33,200 & 43,600 & 57,100 & 67,300 & 77,600 & 101,000 \\
\hline 90 & 0.115 & -0.120 & 14.72 & 47.6 & 38.21 & 758 & 1,940 & 3,130 & 5,170 & 7,110 & 9,430 & 16,600 \\
\hline
\end{tabular}


Table 1. Peak-streamflow frequency estimates and basin characteristics for selected stations with at least 8 years of annual

[ft³/s, cubic feet per second; LPIII, Log-Pearson Type III; mi², square miles; ft/mi, feet per mile; wt, weighted; Trib., Tributary; Ck, creek; Res., Reservoir;

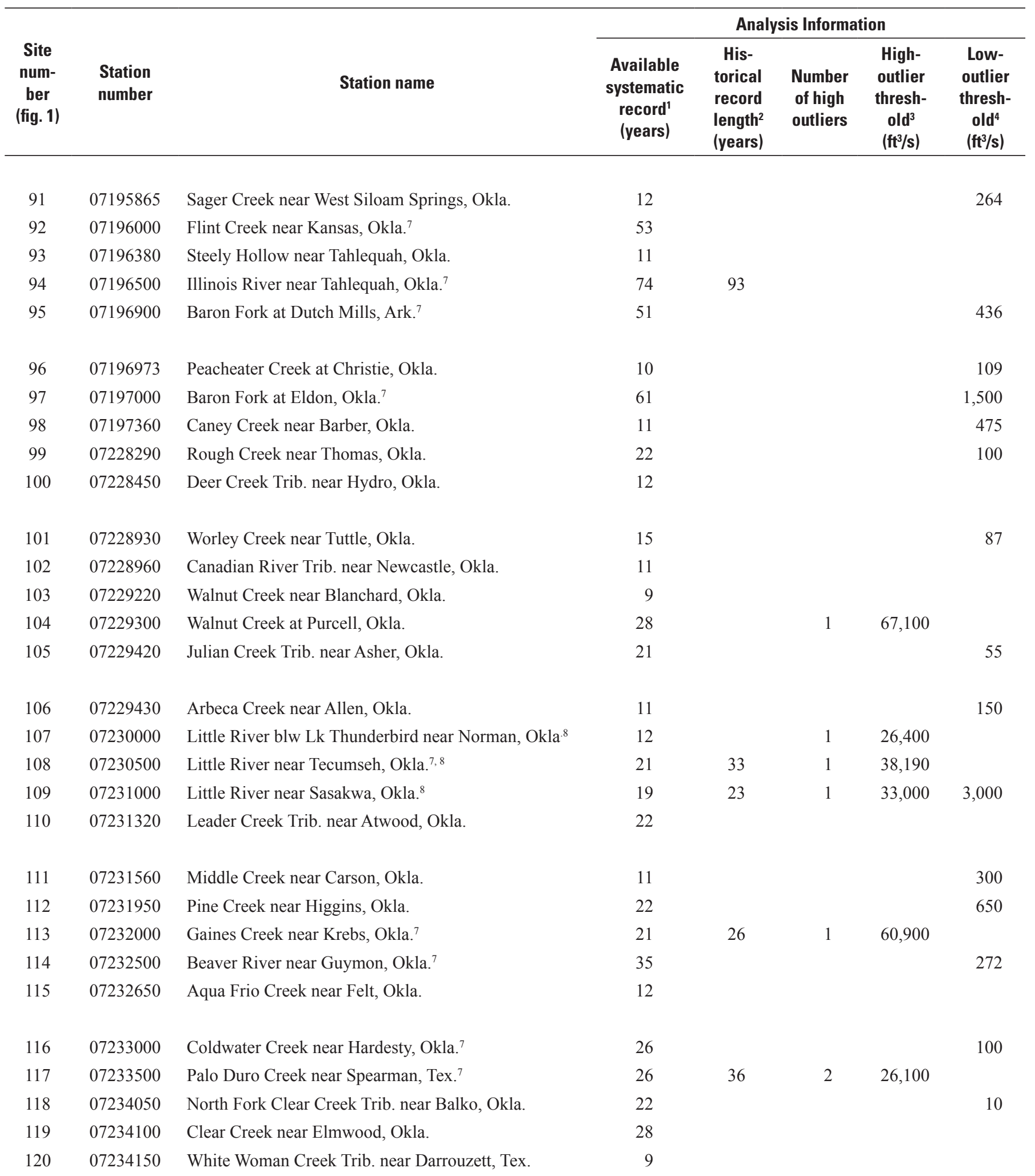


peak-streamflow data from unregulated basins in and near Oklahoma.-Continued

L., Little; Lk, Lake; blw, below; SWS, subwatershed; Fk, Fork; R, river; nr, near; \%, percent; SH, State highway; N, north; ab, above]

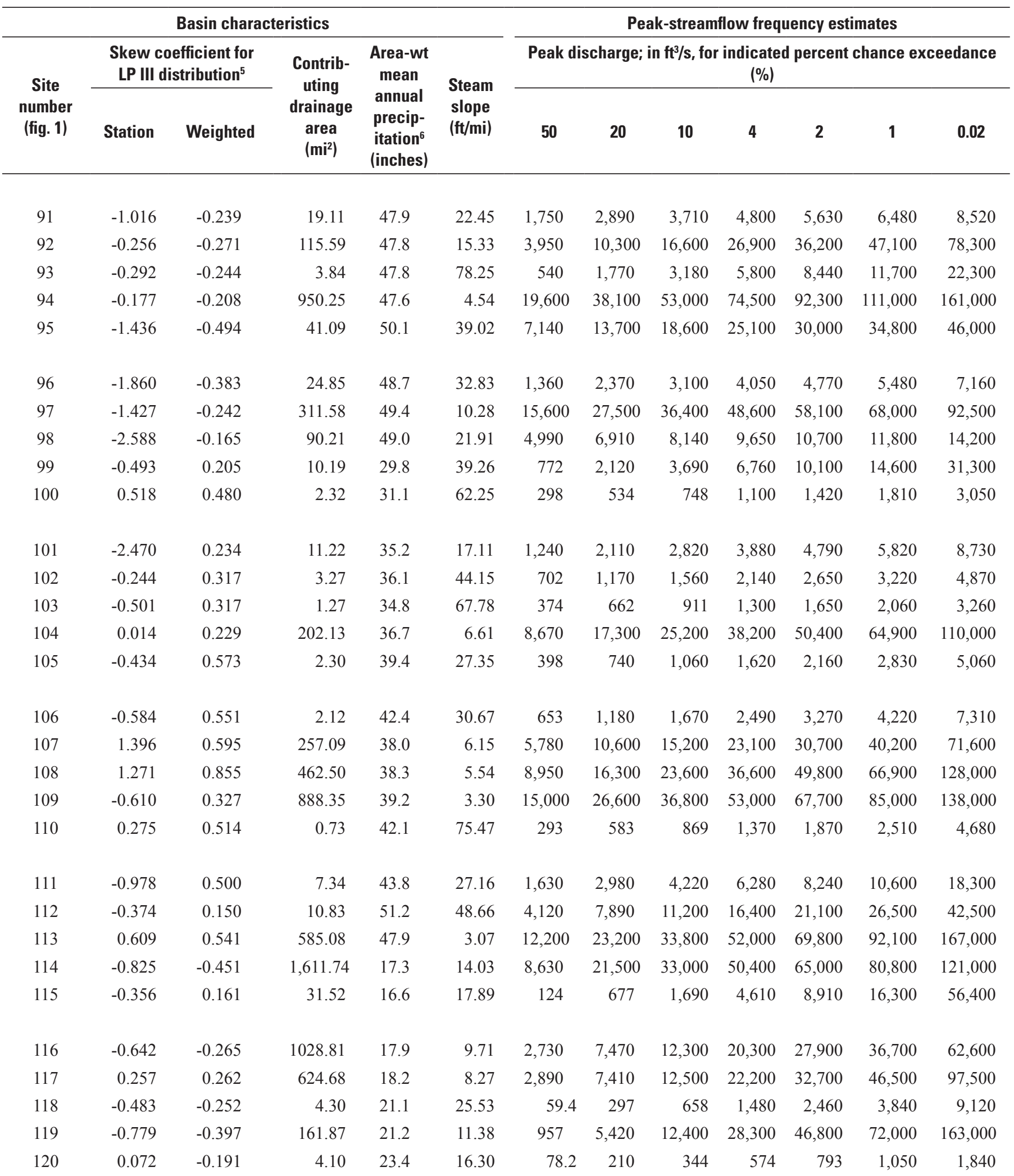


Table 1. Peak-streamflow frequency estimates and basin characteristics for selected stations with at least 8 years of annual

[ft³/s, cubic feet per second; LPIII, Log-Pearson Type III; mi², square miles; ft/mi, feet per mile; wt, weighted; Trib., Tributary; Ck, creek; Res., Reservoir;

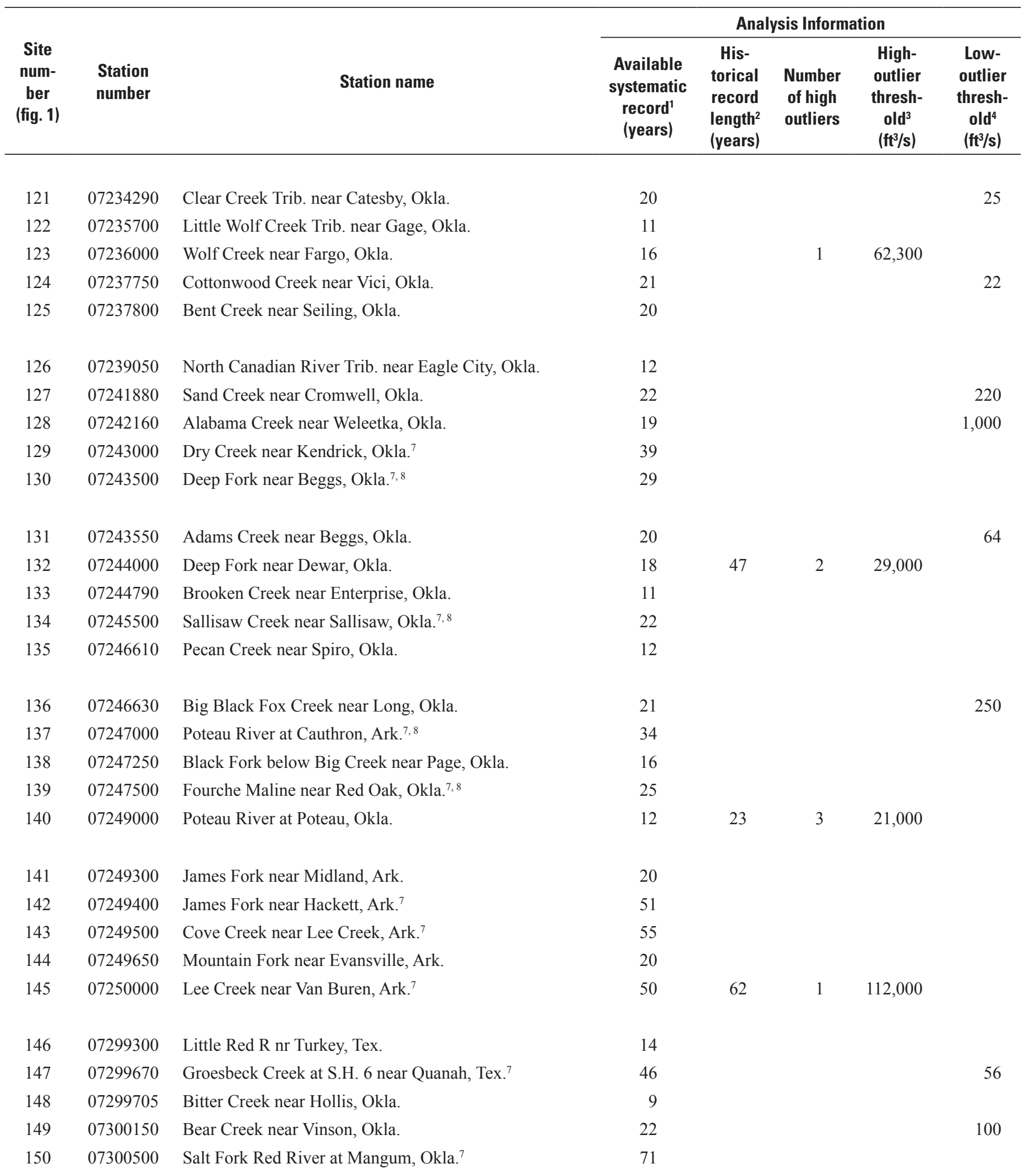


peak-streamflow data from unregulated basins in and near Oklahoma.-Continued

L., Little; Lk, Lake; blw, below; SWS, subwatershed; Fk, Fork; R, river; nr, near; \%, percent; SH, State highway; N, north; ab, above]

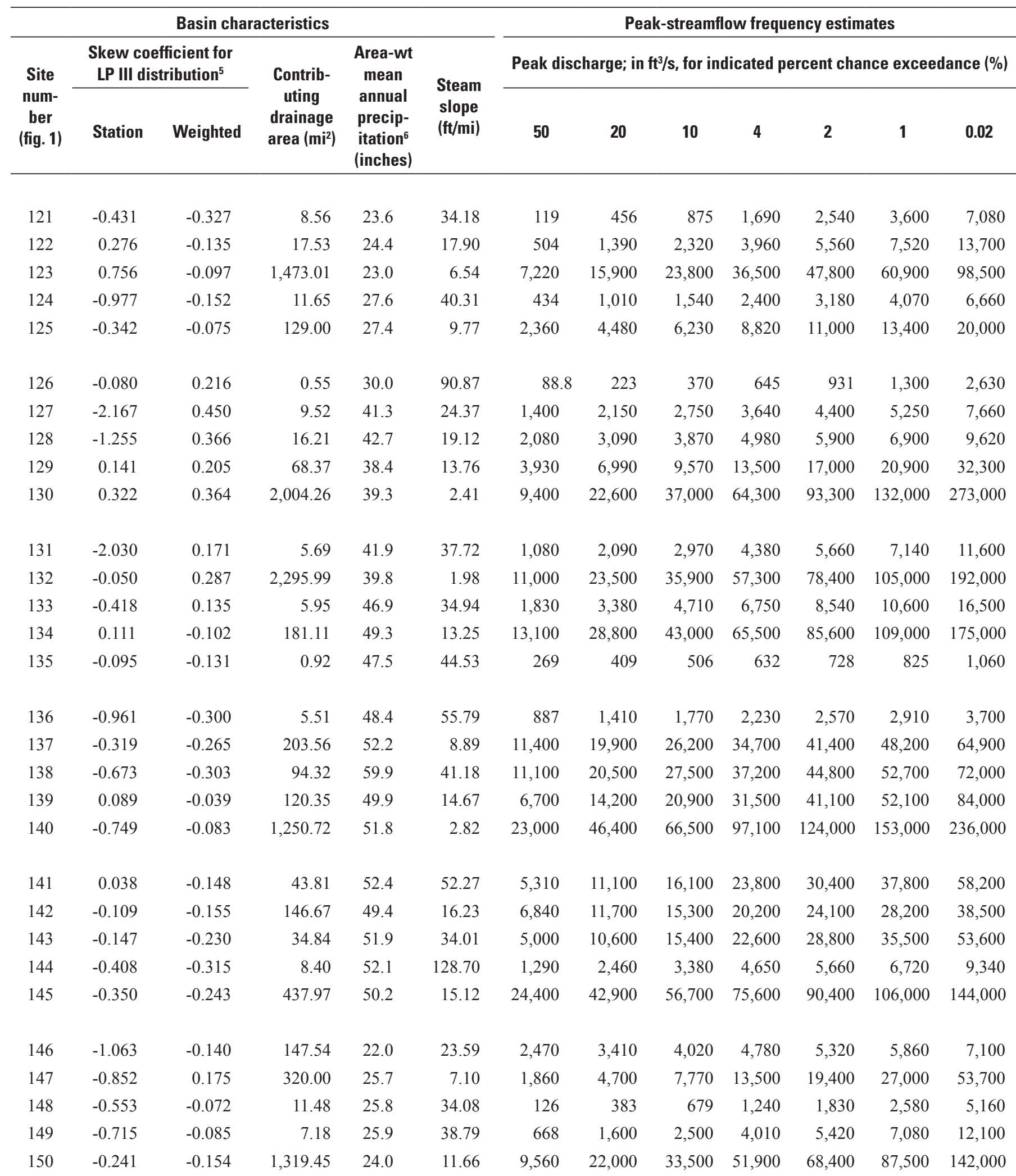


Table 1. Peak-streamflow frequency estimates and basin characteristics for selected stations with at least 8 years of annual

[ft³/s, cubic feet per second; LPIII, Log-Pearson Type III; mi², square miles; ft/mi, feet per mile; wt, weighted; Trib., Tributary; Ck, creek; Res., Reservoir;

\begin{tabular}{|c|c|c|c|c|c|c|c|}
\hline \multirow[b]{2}{*}{$\begin{array}{c}\text { Site } \\
\text { num- } \\
\text { ber } \\
\text { (fig. 1) }\end{array}$} & \multirow[b]{2}{*}{$\begin{array}{l}\text { Station } \\
\text { number }\end{array}$} & \multirow[b]{2}{*}{ Station name } & \multicolumn{5}{|c|}{ Analysis Information } \\
\hline & & & $\begin{array}{c}\text { Available } \\
\text { systematic } \\
\text { record' }^{1} \\
\text { (years) }\end{array}$ & $\begin{array}{l}\text { His- } \\
\text { torical } \\
\text { record } \\
\text { length }{ }^{2} \\
\text { (years) }\end{array}$ & $\begin{array}{c}\text { Number } \\
\text { of high } \\
\text { outliers }\end{array}$ & $\begin{array}{l}\text { High- } \\
\text { outlier } \\
\text { thresh- } \\
\text { old }^{3} \\
\left(\mathrm{ft}^{3} / \mathrm{s}\right)\end{array}$ & $\begin{array}{c}\text { Low- } \\
\text { outlier } \\
\text { thresh- } \\
\text { old } \\
\left(\mathrm{ft}^{3} / \mathrm{s}\right)\end{array}$ \\
\hline 152 & 07301300 & N Fk Red R nr Shamrock, Tex. & 15 & & & & \\
\hline 153 & 07301455 & Turkey Creek near Erick, Okla. & 17 & 22 & & & 218 \\
\hline 154 & 07301480 & Short Creek near Sayre, Okla. & 20 & & & & \\
\hline 155 & 07301500 & North Fork Red River near Carter, Okla. ${ }^{7}$ & 32 & 59 & 2 & 14,300 & 1,375 \\
\hline 158 & 07303500 & Elm Fork of North Fk Red River near Mangum, Okla. ${ }^{7}$ & 72 & & & & \\
\hline 159 & 07304500 & Elk Creek near Hobart, Okla. & 20 & & 1 & 18,300 & \\
\hline 160 & 07309480 & Canyon Creek near Medicine Park, Okla. & 11 & & & & 30 \\
\hline 161 & 07311000 & East Cache Creek near Walters, Okla. ${ }^{8}$ & 22 & & & & 974 \\
\hline 162 & 07311200 & Blue Beaver Creek near Cache, Okla. & 39 & & & & 118 \\
\hline 163 & 07311420 & Deadman Creek Trib. at Manitou, Okla. & 8 & 11 & 1 & 900 & \\
\hline 164 & 07311500 & Deep Red Creek near Randlett, Okla. ${ }^{7}$ & 59 & & & & \\
\hline 165 & 07312850 & Nine Mile Beaver Creek near Elgin, Okla. & 22 & & & & 100 \\
\hline 171 & 07315700 & Mud Creek near Courtney, Okla. ${ }^{7}$ & 48 & 52 & 1 & 30,000 & 211 \\
\hline 172 & 07315880 & Demijohn Creek near Wilson, Okla. & 10 & & & & \\
\hline 173 & 07316130 & Wilson Creek Trib. near McMillan, Okla. & 11 & & & & \\
\hline 174 & 07316140 & Brier Creek near Powell, Okla. & 21 & & & & \\
\hline 175 & 07316500 & Washita River near Cheyenne, Okla., & 23 & 27 & & & \\
\hline 176 & 07317500 & Sandstone Creek SWS 16A near Cheyenne, Okla. ${ }^{9}$ & 21 & & & & \\
\hline 177 & 07318500 & Sandstone Creek SWS 14 near Cheyenne, Okla. ${ }^{9}$ & 12 & 20 & 2 & 1,160 & \\
\hline 178 & 07319000 & Sandstone Creek SWS 17 near Cheyenne, Okla. ${ }^{9}$ & 20 & & & & 49 \\
\hline 179 & 07320000 & Sandstone Creek SWS 10A near Elk City, Okla. ${ }^{9}$ & 19 & 21 & & & \\
\hline 180 & 07321500 & Sandstone Creek SWS 3 near Elk City, Okla. ${ }^{9}$ & 14 & 19 & & & \\
\hline
\end{tabular}


peak-streamflow data from unregulated basins in and near Oklahoma.-Continued

L., Little; Lk, Lake; blw, below; SWS, subwatershed; Fk, Fork; R, river; nr, near; \%, percent; SH, State highway; N, north; ab, above]

\begin{tabular}{|c|c|c|c|c|c|c|c|c|c|c|c|c|}
\hline \multicolumn{6}{|c|}{ Basin characteristics } & \multicolumn{7}{|c|}{ Peak-streamflow frequency estimates } \\
\hline \multirow{2}{*}{$\begin{array}{c}\text { Site } \\
\text { num- } \\
\text { ber } \\
\text { (fig. 1) }\end{array}$} & \multicolumn{2}{|c|}{$\begin{array}{l}\text { Skew coefficient for } \\
\text { LP III distribution }\end{array}$} & \multirow{2}{*}{$\begin{array}{c}\text { Contrib- } \\
\text { uting } \\
\text { drainage } \\
\text { area }\left(\mathrm{mi}^{2}\right)\end{array}$} & \multirow{2}{*}{$\begin{array}{c}\text { Area-wt } \\
\text { mean } \\
\text { annual } \\
\text { precip- } \\
\text { itation }^{6} \\
\text { (inches) }^{2}\end{array}$} & \multirow{2}{*}{$\begin{array}{l}\text { Steam } \\
\text { slope } \\
\text { (ft/mi) }\end{array}$} & \multicolumn{7}{|c|}{ Peak discharge; in $\mathrm{ft}^{3} / \mathrm{s}$, for indicated percent chance exceedance $(\%$} \\
\hline & Station & Weighted & & & & 50 & 20 & 10 & 4 & 2 & 1 & 0.02 \\
\hline 152 & 0.780 & -0.024 & 816.73 & 22.9 & 10.36 & 6,460 & 10,100 & 12,700 & 16,200 & 19,000 & 21,900 & 29,200 \\
\hline 153 & -1.204 & -0.382 & 21.87 & 26.1 & 17.30 & 1,070 & 1,910 & 2,520 & 3,320 & 3,930 & 4,550 & 6,000 \\
\hline 154 & 0.298 & 0.044 & 9.28 & 26.3 & 31.62 & 456 & 926 & 1,340 & 2,010 & 2,600 & 3,300 & 5,320 \\
\hline 155 & -0.285 & -0.151 & 2072.51 & 24.1 & 9.57 & 8,410 & 14,800 & 19,600 & 26,400 & 31,900 & 37,600 & 52,300 \\
\hline 158 & -0.548 & -0.203 & 846.33 & 26.2 & 10.87 & 7,300 & 15,900 & 23,600 & 35,200 & 45,400 & 56,700 & 87,800 \\
\hline 159 & 0.818 & 0.244 & 549.28 & 28.7 & 6.33 & 3,990 & 6,880 & 9,280 & 12,900 & 16,100 & 19,700 & 30,000 \\
\hline 160 & -1.697 & 0.159 & 3.39 & 32.8 & 56.74 & 762 & 1,880 & 3,070 & 5,230 & 7,430 & 10,200 & 19,800 \\
\hline 161 & -0.985 & 0.159 & 693.50 & 32.9 & 5.07 & 7,590 & 13,400 & 18,200 & 25,500 & 31,800 & 38,800 & 58,900 \\
\hline 162 & -0.302 & 0.211 & 24.67 & 32.6 & 35.58 & 1,650 & 3,600 & 5,500 & 8,780 & 12,000 & 15,900 & 28,700 \\
\hline 163 & -0.238 & 0.080 & 2.58 & 30.1 & 31.93 & 357 & 771 & 1,160 & 1,810 & 2,410 & 3,130 & 5,340 \\
\hline 164 & -0.044 & 0.019 & 604.08 & 30.8 & 5.92 & 7,220 & 16,800 & 26,100 & 41,900 & 56,900 & 75,000 & 131,000 \\
\hline 165 & -0.589 & 0.259 & 6.36 & 33.9 & 39.94 & 703 & 1,740 & 2,880 & 5,000 & 7,240 & 10,200 & 20,600 \\
\hline 171 & -0.353 & 0.190 & 574.41 & 35.1 & 3.89 & 5,920 & 15,200 & 25,400 & 44,530 & 64,560 & 90,690 & 183,400 \\
\hline 172 & -0.949 & 0.065 & 6.44 & 36.9 & 30.34 & 1,880 & 2,160 & 2,330 & 2,530 & 2,660 & 2,790 & 3,070 \\
\hline 173 & -0.327 & 0.068 & 2.95 & 40.3 & 43.67 & 768 & 1,110 & 1,350 & 1,660 & 1,900 & 2,150 & 2,770 \\
\hline 174 & 0.281 & 0.152 & 11.99 & 42.2 & 25.65 & 2,930 & 5,450 & 7,630 & 11,000 & 14,000 & 17,400 & 27,400 \\
\hline 175 & 0.108 & 0.043 & 762.59 & 24.2 & 8.96 & 5,610 & 15,500 & 26,600 & 47,200 & 68,700 & 96,300 & 192,000 \\
\hline 176 & 0.337 & 0.066 & 9.68 & 25.8 & 45.39 & 451 & 1,070 & 1,700 & 2,780 & 3,830 & 5,130 & 9,290 \\
\hline 177 & -0.220 & -0.014 & 1.01 & 26.7 & 116.64 & 274 & 632 & 979 & 1,560 & 2,100 & 2,750 & 4,740 \\
\hline 178 & -0.858 & -0.095 & 11.11 & 26.0 & 51.32 & 979 & 2,370 & 3,740 & 6,020 & 8,150 & 10,700 & 18,400 \\
\hline 179 & -1.300 & -0.078 & 2.79 & 27.0 & 75.30 & 750 & 1,250 & 1,620 & 2,130 & 2,540 & 2,970 & 4,060 \\
\hline 180 & -1.041 & 0.116 & 0.65 & 27.4 & 107.51 & 311 & 616 & 890 & 1,320 & 1,720 & 2,180 & 3,540 \\
\hline
\end{tabular}


Table 1. Peak-streamflow frequency estimates and basin characteristics for selected stations with at least 8 years of annual

[ft³/s, cubic feet per second; LPIII, Log-Pearson Type III; mi², square miles; ft/mi, feet per mile; wt, weighted; Trib., Tributary; Ck, creek; Res., Reservoir;

\begin{tabular}{|c|c|c|c|c|c|c|c|}
\hline \multirow[b]{2}{*}{$\begin{array}{c}\text { Site } \\
\text { num- } \\
\text { ber } \\
\text { (fig. 1) }\end{array}$} & \multirow[b]{2}{*}{$\begin{array}{l}\text { Station } \\
\text { number }\end{array}$} & \multirow[b]{2}{*}{ Station name } & \multicolumn{5}{|c|}{ Analysis Information } \\
\hline & & & $\begin{array}{l}\text { Available } \\
\text { systematic } \\
\text { record'1 } \\
\text { (years) }\end{array}$ & $\begin{array}{l}\text { His- } \\
\text { torical } \\
\text { record } \\
\text { length }{ }^{2} \\
\text { (years) }\end{array}$ & $\begin{array}{l}\text { Number } \\
\text { of high } \\
\text { outliers }\end{array}$ & $\begin{array}{l}\text { High- } \\
\text { outlier } \\
\text { thresh- } \\
\text { old }^{3} \\
\left(\mathrm{ft}^{3} / \mathrm{s}\right)\end{array}$ & $\begin{array}{c}\text { Low- } \\
\text { outlier } \\
\text { thresh- } \\
\text { old }^{4} \\
\left.\text { (ft }{ }^{3} / \mathrm{s}\right)\end{array}$ \\
\hline 182 & 07324000 & Sandstone Creek SWS 1 near Cheyenne, Okla. ${ }^{9}$ & 18 & 22 & & & \\
\hline 183 & 07325000 & Washita River near Clinton, Okla. ${ }^{7,8}$ & 27 & & & & \\
\hline 184 & 07325850 & Lake Creek near Eakly, Okla. & 13 & & & & \\
\hline 185 & 07326000 & Cobb Creek near Fort Cobb, Okla. ${ }^{8}$ & 19 & 22 & 1 & 32,500 & \\
\hline 188 & 07327440 & East Bitter Creek near Tabler, Okla. ${ }^{8}$ & 10 & & & & \\
\hline 189 & 073274406 & Little Washita River ab SCS Pond No 26 nr Cyril, Okla. & 14 & & & & \\
\hline 190 & 07327490 & Little Washita River near Ninnekah, Okla. ${ }^{7,8}$ & 22 & 27 & 1 & 24,900 & \\
\hline 191 & 07329000 & Rush Creek at Purdy, Okla. ${ }^{8}$ & 15 & & & & \\
\hline 192 & 07329500 & 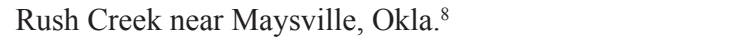 & 11 & & & & \\
\hline 193 & 07329810 & Honey Creek near Davis, Okla. & 21 & & & & 37 \\
\hline 194 & 07329900 & Rock Creek at Dougherty, Okla. ${ }^{8}$ & 15 & & & & 273 \\
\hline 195 & 07330500 & Caddo Creek near Ardmore, Okla. & 14 & & & & 926 \\
\hline 201 & 07333800 & McGee Creek near Stringtown, Okla. & 20 & & & & 2,900 \\
\hline 202 & 07334000 & Muddy Boggy Creek near Farris, Okla., & 49 & & & & \\
\hline 203 & 07335000 & Clear Boggy Creek near Caney, Okla. ${ }^{7,8}$ & 20 & 24 & 1 & 54,600 & \\
\hline 204 & 07335310 & Rock Creek near Boswell, Okla. & 21 & & & & \\
\hline 205 & 07335320 & Bokchito Creek near Soper, Okla. & 11 & & & & 670 \\
\hline 206 & 07335700 & Kiamichi River near Big Cedar, Okla. & 43 & & & & 1,428 \\
\hline 207 & 07335760 & Kiamichi River Trib. near Albion, Okla. & 8 & & & & \\
\hline 208 & 07336000 & Tenmile Creek near Miller, Okla. & 29 & & 1 & 9,810 & \\
\hline 209 & 07336500 & Kiamichi River near Belzoni, Okla. ${ }^{7}$ & 47 & 57 & & & \\
\hline 210 & 07336520 & Frazier Creek near Oleta, Okla. & 22 & & & & \\
\hline
\end{tabular}


peak-streamflow data from unregulated basins in and near Oklahoma.-Continued

L., Little; Lk, Lake; blw, below; SWS, subwatershed; Fk, Fork; R, river; nr, near; \%, percent; SH, State highway; N, north; ab, above]

\begin{tabular}{|c|c|c|c|c|c|c|c|c|c|c|c|c|}
\hline \multicolumn{6}{|c|}{ Basin characteristics } & \multicolumn{7}{|c|}{ Peak-streamflow frequency estimates } \\
\hline \multirow{2}{*}{$\begin{array}{c}\text { Site } \\
\text { num- } \\
\text { ber } \\
\text { (fig. } \\
\text { 1) }\end{array}$} & \multicolumn{2}{|c|}{$\begin{array}{l}\text { Skew coefficient for } \\
\text { LP III distribution }\end{array}$} & \multirow{2}{*}{$\begin{array}{l}\text { Contrib- } \\
\text { uting } \\
\text { drainage } \\
\text { area }\left(\mathrm{mi}^{2}\right)\end{array}$} & \multirow{2}{*}{$\begin{array}{l}\text { Area-wt } \\
\text { mean } \\
\text { annual } \\
\text { precip- } \\
\text { itation }^{6} \\
\text { (inches) }\end{array}$} & \multirow{2}{*}{$\begin{array}{l}\text { Steam } \\
\text { slope } \\
\text { (ft/mi) }\end{array}$} & \multicolumn{7}{|c|}{ Peak discharge; in $\mathrm{ft}^{3} / \mathrm{s}$, for indicated percent chance exceedance $(\%)$} \\
\hline & Station & Weighted & & & & 50 & 20 & 10 & 4 & 2 & 1 & 0.02 \\
\hline 181 & -0.197 & 0.010 & 3.36 & 27.4 & 60.09 & 868 & 1,580 & 2,160 & 3,010 & 3,740 & 4,550 & 6,740 \\
\hline 182 & -0.340 & 0.082 & 5.39 & 27.5 & 46.93 & 812 & 1,930 & 3,070 & 5,050 & 7,000 & 9,400 & 17,200 \\
\hline 183 & 0.678 & 0.507 & $1,948.58$ & 26.4 & 6.79 & 7,650 & 18,200 & 30,000 & 53,100 & 78,500 & 113,000 & 247,000 \\
\hline 184 & 0.413 & 0.459 & 52.46 & 31.6 & 15.90 & 935 & 2,840 & 5,380 & 11,100 & 18,200 & 28,800 & 76,500 \\
\hline 185 & 0.851 & 0.556 & 310.72 & 31.4 & 7.23 & 4,220 & 10,200 & 17,200 & 31,200 & 47,000 & 68,900 & 157,000 \\
\hline 186 & 0.089 & 0.436 & 23.79 & 34.1 & 13.17 & 694 & 1,620 & 2,620 & 4,530 & 6,560 & 9,260 & 19,300 \\
\hline 187 & -1.523 & 0.270 & 59.70 & 34.0 & 10.89 & 1,630 & 3,080 & 4,380 & 6,470 & 8,380 & 10,600 & 17,600 \\
\hline 188 & -0.582 & 0.338 & 35.38 & 34.6 & 12.23 & 1,710 & 2,990 & 4,100 & 5,820 & 7,360 & 9,150 & 14,500 \\
\hline 189 & -0.717 & 0.263 & 3.65 & 33.4 & 37.74 & 391 & 1,350 & 2,660 & 5,670 & 9,380 & 14,900 & 39,200 \\
\hline 190 & 0.413 & 0.544 & 207.96 & 34.4 & 8.52 & 3,250 & 7,430 & 12,000 & 20,900 & 30,500 & 43,500 & 93,300 \\
\hline 191 & 0.244 & 0.344 & 139.68 & 36.6 & 9.97 & 10,000 & 16,100 & 21,000 & 28,300 & 34,500 & 41,500 & 61,200 \\
\hline 192 & 0.003 & 0.280 & 201.75 & 36.9 & 8.78 & 9,390 & 17,800 & 25,300 & 37,400 & 48,600 & 61,900 & 102,000 \\
\hline 193 & -2.175 & 0.132 & 18.75 & 39.6 & 41.48 & 1,940 & 4,610 & 7,340 & 12,200 & 16,900 & 22,900 & 42,600 \\
\hline 194 & -1.027 & 0.226 & 136.76 & 41.2 & 13.71 & 4,650 & 10,500 & 16,500 & 27,000 & 37,400 & 50,500 & 94,200 \\
\hline 195 & -1.260 & 0.054 & 296.30 & 38.0 & 5.81 & 8,300 & 15,500 & 21,600 & 30,800 & 38,800 & 47,800 & 73,200 \\
\hline 196 & 0.587 & 0.199 & 0.71 & 43.5 & 27.10 & 397 & 684 & 919 & 1,270 & 1,580 & 1,920 & 2,890 \\
\hline 197 & -0.426 & -0.120 & 203.19 & 42.3 & 10.26 & 8,700 & 17,300 & 24,500 & 35,300 & 44,600 & 54,800 & 82,700 \\
\hline 198 & -0.216 & 0.367 & 477.45 & 43.5 & 6.98 & 9,300 & 17,100 & 24,000 & 35,300 & 45,650 & 58,000 & 96,200 \\
\hline 199 & -2.187 & -0.322 & 72.09 & 43.3 & 8.38 & 8,880 & 12,500 & 14,700 & 17,400 & 19,300 & 21,000 & 25,000 \\
\hline 200 & -1.184 & 0.177 & 32.62 & 45.5 & 25.39 & 7,570 & 10,800 & 13,200 & 16,300 & 18,700 & 21,300 & 27,700 \\
\hline 201 & -1.761 & 0.113 & 88.76 & 47.4 & 6.10 & 6,840 & 8,630 & 9,770 & 11,200 & 12,200 & 13,200 & 15,600 \\
\hline 202 & -0.164 & 0.056 & 1088.92 & 45.0 & 3.18 & 19,200 & 29,800 & 37,600 & 48,300 & 56,900 & 65,900 & 88,900 \\
\hline 203 & 0.050 & 0.167 & 713.37 & 43.4 & 3.37 & 14,000 & 28,600 & 42,200 & 64,400 & 85,200 & 110,000 & 186,000 \\
\hline 204 & -0.685 & -0.067 & 1.01 & 46.0 & 33.38 & 249 & 427 & 564 & 756 & 912 & 1,080 & 1,510 \\
\hline 205 & -1.270 & -0.071 & 17.48 & 47.1 & 15.74 & 3,230 & 5,090 & 6,430 & 8,230 & 9,640 & 11,100 & 14,700 \\
\hline 206 & -0.647 & -0.258 & 39.63 & 62.1 & 54.89 & 9,200 & 15,100 & 19,300 & 24,800 & 29,000 & 33,300 & 43,400 \\
\hline 207 & 0.530 & -0.511 & 1.51 & 55.9 & 342.93 & 246 & 549 & 797 & 1,150 & 1,420 & 1,710 & 2,400 \\
\hline 208 & 0.617 & 0.281 & 68.31 & 48.1 & 12.21 & 3,620 & 5,080 & 6,120 & 7,530 & 8,650 & 9,830 & 12,800 \\
\hline 209 & -0.147 & -0.059 & 1415.94 & 51.3 & 3.35 & 34,300 & 49,400 & 59,600 & 72,700 & 82,500 & 92,500 & 116,000 \\
\hline 210 & -0.184 & -0.061 & 18.54 & 50.8 & 25.32 & 2,480 & 4,560 & 6,250 & 8,710 & 10,800 & 13,000 & 19,100 \\
\hline
\end{tabular}


Table 1. Peak-streamflow frequency estimates and basin characteristics for selected stations with at least 8 years of annual

$\left[\mathrm{ft}^{3} / \mathrm{s}\right.$, cubic feet per second; LPIII, Log-Pearson Type III; $\mathrm{mi}^{2}$, square miles; ft/mi, feet per mile; wt, weighted; Trib., Tributary; Ck, creek; Res., Reservoir;

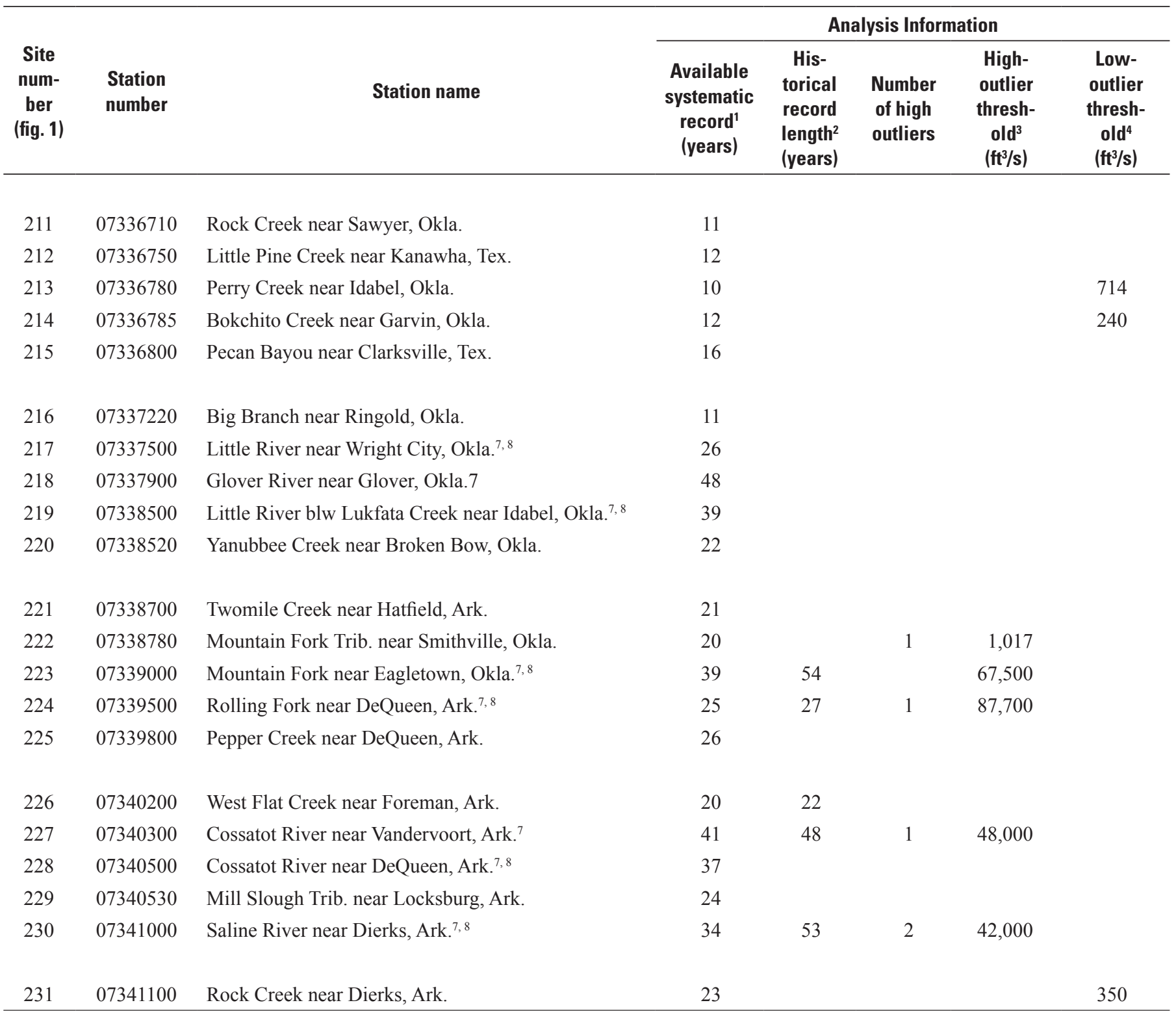

${ }^{1}$ Available systematic record reflects number of annual peak discharges from natural basins. Many stations became regulated during the period of operation. Regulated annual peak discharges not included in peak-streamflow frequency analysis.

${ }^{2}$ Historical record length reflects that known as of 2008 water year.

${ }^{3}$ High-outlier threshold based on available historical streamflow data.

${ }^{4}$ Low-outlier threshold used in frequency analysis; provided by PeakFQ by using Interagency Advisory Committee on Water Data (1982) techniques or visual by author.

${ }^{5}$ Reflects weighting adjusted station skew with skew value from Oklahoma generalized skew map (fig. 2; Lewis and Esralew, 2009).

${ }^{6}$ Values at station location derived from geographical information system using gridded mean-annual precipitation based on 1971-2000 data.

${ }^{7}$ Station used in construction of Oklahoma generalized skew map (fig. 2; Lewis and Esralew, 2009).

${ }^{8}$ Station has an unregulated period of record used in the analysis, but now is regulated.

${ }^{9}$ Streamflow data computed from inflow to floodwater retarding structure. 
peak-streamflow data from unregulated basins in and near Oklahoma.-Continued

L., Little; Lk, Lake; blw, below; SWS, subwatershed; Fk, Fork; R, river; nr, near; \%, percent; SH, State highway; N, north; ab, above]

\begin{tabular}{|c|c|c|c|c|c|c|c|c|c|c|c|c|}
\hline \multicolumn{6}{|c|}{ Basin characteristics } & \multicolumn{7}{|c|}{ Peak-streamflow frequency estimates } \\
\hline \multirow{2}{*}{$\begin{array}{c}\text { Site } \\
\text { num- } \\
\text { ber } \\
\text { (fig. 1) }\end{array}$} & \multicolumn{2}{|c|}{$\begin{array}{l}\text { Skew coefficient for } \\
\text { LP III distribution }\end{array}$} & \multirow{2}{*}{$\begin{array}{l}\text { Contrib- } \\
\text { uting } \\
\text { drainage } \\
\text { area }\left(\mathrm{mi}^{2}\right)\end{array}$} & \multirow{2}{*}{$\begin{array}{c}\text { Area-wt } \\
\text { mean } \\
\text { annual } \\
\text { precip- } \\
\text { itation }^{6} \\
\text { (inches) }\end{array}$} & \multirow{2}{*}{$\begin{array}{l}\text { Steam } \\
\text { slope } \\
\text { (ft/mi) }\end{array}$} & \multicolumn{7}{|c|}{ Peak discharge; in $\mathrm{ft}^{3} / \mathrm{s}$, for indicated percent chance exceedance $(\%)$} \\
\hline & Station & Weighted & & & & 50 & 20 & 10 & 4 & 2 & 1 & 0.02 \\
\hline 211 & 0.156 & -0.022 & 3.33 & 49.4 & 33.06 & 794 & 1,170 & 1,430 & 1,770 & 2,040 & 2,310 & 2,960 \\
\hline 212 & -0.142 & -0.118 & 75.27 & 48.8 & 5.24 & 6,180 & 12,600 & 18,200 & 26,600 & 33,900 & 42,000 & 64,500 \\
\hline 213 & -0.955 & 0.054 & 7.60 & 51.1 & 22.72 & 2,240 & 3,020 & 3,540 & 4,190 & 4,680 & 5,180 & 6,350 \\
\hline 214 & -1.071 & -0.172 & 2.89 & 51.1 & 22.67 & 731 & 1,020 & 1,200 & 1,430 & 1,600 & 1,760 & 2,130 \\
\hline 215 & -0.422 & -0.201 & 98.91 & 49.2 & 4.30 & 4,060 & 8,050 & 11,300 & 16,100 & 20,200 & 24,500 & 36,000 \\
\hline 216 & 0.385 & 0.023 & 1.99 & 52.2 & 72.35 & 448 & 856 & 1,200 & 1,730 & 2,190 & 2,710 & 4,160 \\
\hline 217 & -0.042 & -0.047 & 648.22 & 53.9 & 9.74 & 30,500 & 49,700 & 64,100 & 83,800 & 99,500 & 116,000 & 158,000 \\
\hline 218 & 0.150 & 0.033 & 320.28 & 55.3 & 13.52 & 27,700 & 45,100 & 58,300 & 76,800 & 91,700 & 108,000 & 149,000 \\
\hline 219 & -0.055 & -0.058 & $1,228.14$ & 53.9 & 5.67 & 27,600 & 46,100 & 60,000 & 79,400 & 95,100 & 112,000 & 154,000 \\
\hline 220 & -0.394 & -0.145 & 9.03 & 53.8 & 42.27 & 1,770 & 3,100 & 4,130 & 5,550 & 6,700 & 7,920 & 11,000 \\
\hline 221 & 0.394 & -0.070 & 16.22 & 60.0 & 44.03 & 2,040 & 3,570 & 4,760 & 6,460 & 7,850 & 9,340 & 13,200 \\
\hline 222 & 0.505 & -0.020 & 0.65 & 56.1 & 69.96 & 203 & 359 & 482 & 660 & 808 & 968 & 1,400 \\
\hline 223 & -0.469 & -0.223 & 799.80 & 57.4 & 6.82 & 37,400 & 62,900 & 81,600 & 106,000 & 126,000 & 146,000 & 194,000 \\
\hline 224 & 0.139 & -0.098 & 183.37 & 56.4 & 17.52 & 16,300 & 31,600 & 44,300 & 63,100 & 79,200 & 96,800 & 145,000 \\
\hline 225 & -0.503 & -0.138 & 6.27 & 55.9 & 41.72 & 976 & 2,410 & 3,800 & 6,130 & 8,300 & 10,800 & 18,500 \\
\hline 226 & -0.633 & -0.151 & 10.65 & 50.8 & 10.62 & 1,540 & 2,640 & 3,470 & 4,610 & 5,520 & 6,480 & 8,880 \\
\hline 227 & -0.525 & -0.253 & 89.10 & 62.0 & 28.55 & 14,300 & 24,000 & 31,000 & 40,300 & 47,500 & 54,800 & 72,400 \\
\hline 228 & 0.225 & 0.076 & 361.22 & 58.7 & 15.46 & 28,100 & 46,800 & 61,300 & 82,100 & 99,200 & 118,000 & 168,000 \\
\hline 229 & -0.351 & -0.079 & 0.69 & 54.7 & 55.83 & 183 & 344 & 476 & 669 & 838 & 1,010 & 1,490 \\
\hline 230 & 0.113 & 0.009 & 120.21 & 59.1 & 20.90 & 9,740 & 18,500 & 26,000 & 37,200 & 46,900 & 57,900 & 88,500 \\
\hline 231 & -0.552 & -0.027 & 9.39 & 56.9 & 41.95 & 2,220 & 4,280 & 6,020 & 8,640 & 10,900 & 13,400 & 20,500 \\
\hline
\end{tabular}


42 Methods for Estimating the Magnitude and Frequency of Peak Streamflows for Unregulated Streams in Oklahoma

Publishing support provided by:

Lafayette Publishing Service Center

For more information concerning this publication, contact:

Director, USGS Oklahoma Water Science Center

202 NW 66th St., Bldg. 7

Oklahoma City, OK 73116

(405) 810-4400

Or visit the Oklahoma Water Science Center Web site at: http://ok.water.usgs.gov 